Prepared in cooperation with the New Mexico Environment Department and the New Mexico Interstate Stream Commission

\title{
Variability of Surface-Water Quantity and Quality and Shallow Groundwater Levels and Quality Within the Rio Grande Project Area, New Mexico and Texas, 2009-13
}

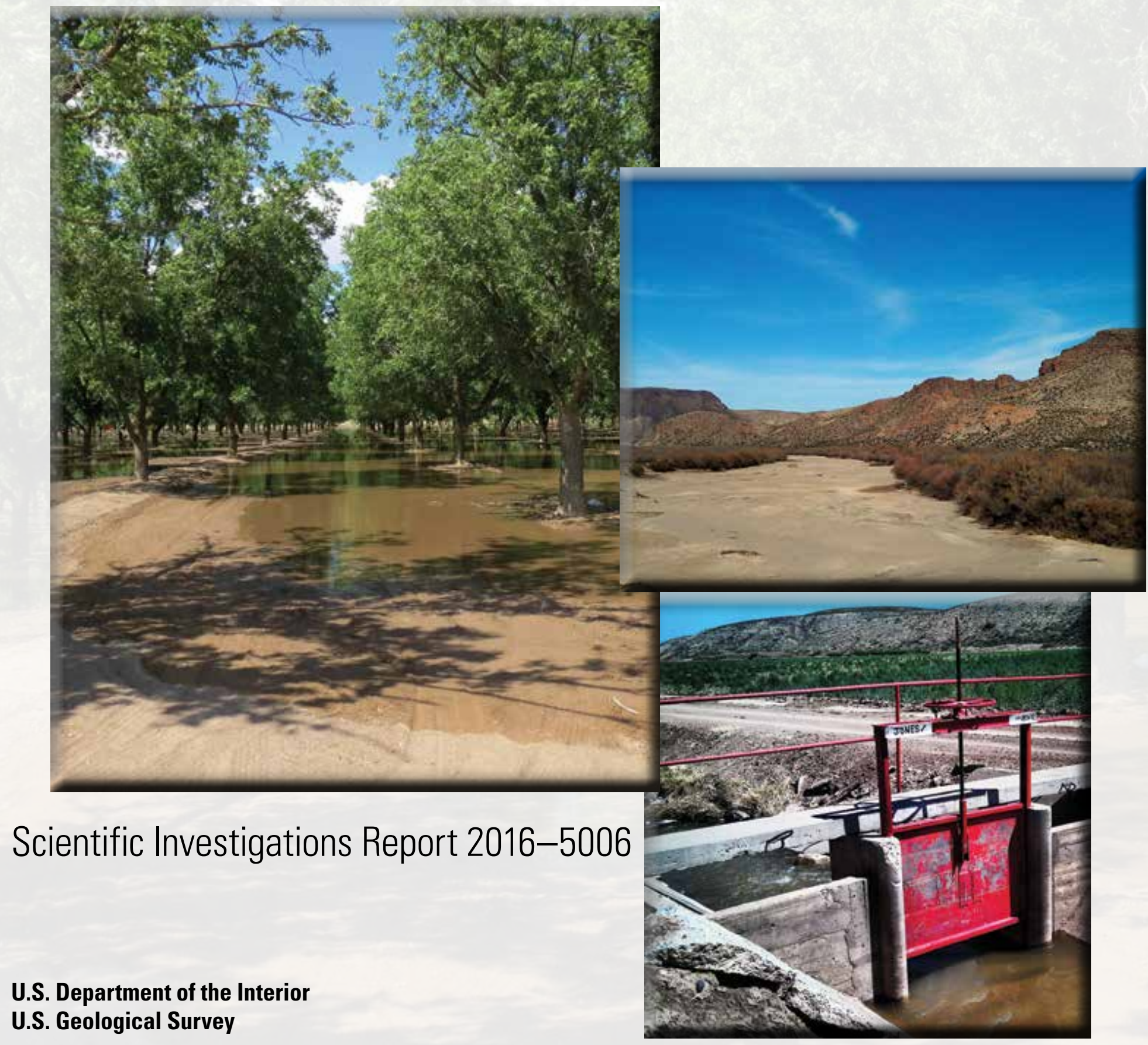




\section{Cover:}

Left, Flood irrigation of pecan orchards in the Rio Grande Project area, New Mexico, June 2014.

Right, Dry Rio Grande riverbed near Selden Canyon, New Mexico, December 2014.

Bottom, Irrigation conveyance and gate with row crops in the background, Rio Grande Project area, New Mexico, June 2014.

U.S. Geological Survey photographs by Jessica M. Driscoll. 


\section{Variability of Surface-Water Quantity and Quality and Shallow Groundwater Levels and Quality Within the Rio Grande Project Area, New Mexico and Texas, 2009-13}

By Jessica M. Driscoll and Lauren R. Sherson

Prepared in cooperation with the New Mexico Environment Department and the

New Mexico Interstate Stream Commission

Scientific Investigations Report 2016-5006 


\title{
U.S. Department of the Interior SALLY JEWELL, Secretary
}

\section{U.S. Geological Survey Suzette M. Kimball, Director}

\author{
U.S. Geological Survey, Reston, Virginia: 2016
}

For more information on the USGS - the Federal source for science about the Earth, its natural and living resources, natural hazards, and the environment—visit http://www.usgs.gov or call 1-888-ASK-USGS.

For an overview of USGS information products, including maps, imagery, and publications, visit http://www.usgs.gov/pubprod/.

Any use of trade, firm, or product names is for descriptive purposes only and does not imply endorsement by the U.S. Government.

Although this information product, for the most part, is in the public domain, it also may contain copyrighted materials as noted in the text. Permission to reproduce copyrighted items must be secured from the copyright owner.

Suggested citation:

Driscoll, J.M., and Sherson, L.R., 2016, Variability of surface-water quantity and quality and shallow groundwater levels and quality within the Rio Grande Project area, New Mexico and Texas, 2009-13: U.S. Geological Survey Scientific Investigations Report 2016-5006, 33 p., http://dx.doi.org/10.3133/sir20165006.

ISSN 2328-0328 (online) 


\section{Contents}

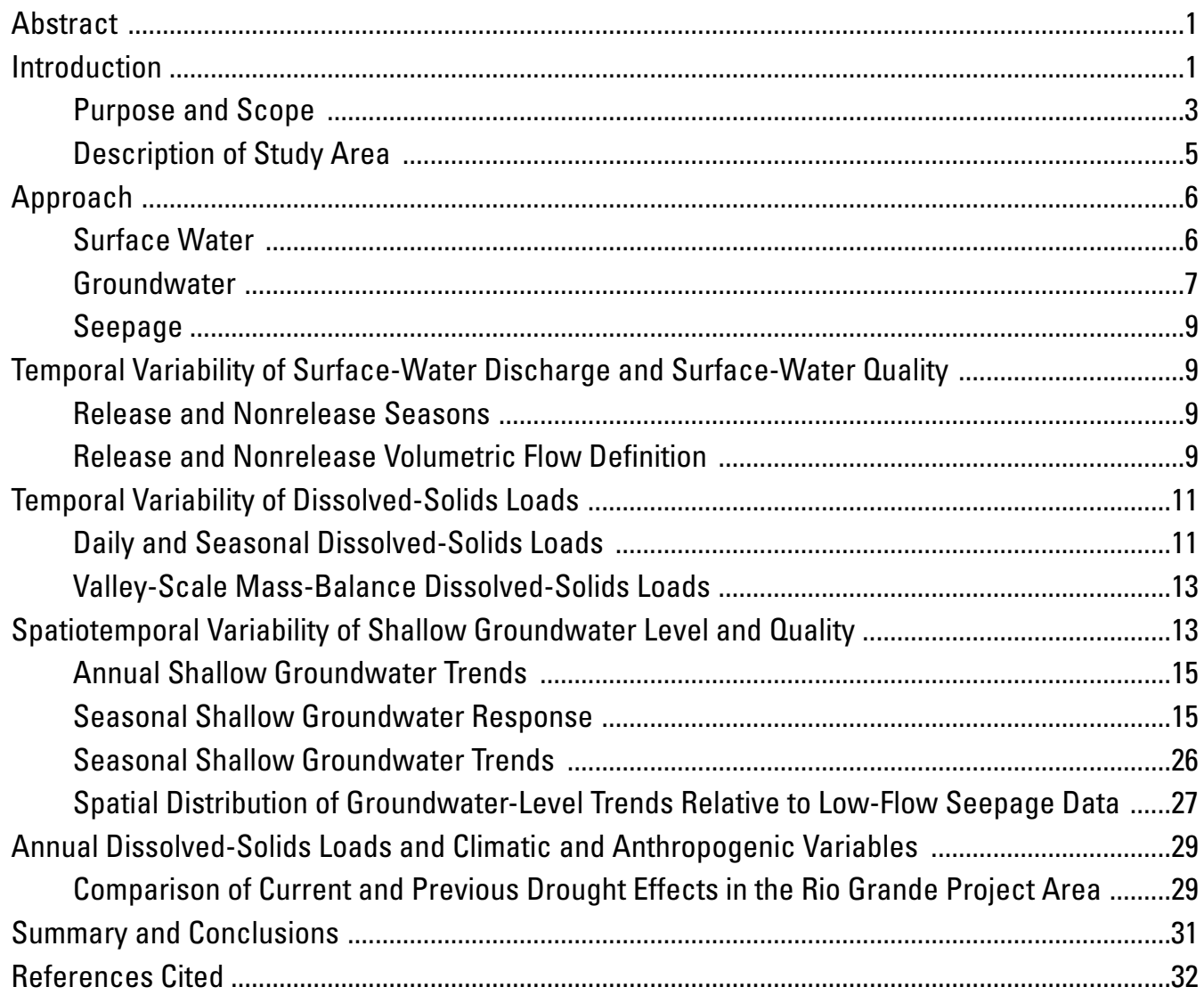

\section{Figures}

1. Map showing location of the Rio Grande Project area and groundwater basins, New Mexico and Texas

2. Map showing location of the Rincon and Mesilla Valleys within the Rio Grande Project area, New Mexico and Texas

3. Graph showing discrete specific-conductance and dissolved-solids data from surface-water samples collected in the Rio Grande Project area, New Mexico and Texas, 2009-13

4. Daily surface-water discharge and specific conductance at three Rio Grande streamgages: Rio Grande below Caballo Dam; Rio Grande below Leasburg Dam; and Rio Grande at El Paso from January 1, 2009, to September 30, 2013

5. Seasonal and annual dissolved-solids loads from 2009 to 2013 in the Rio Grande Project area: $A$, Rio Grande below Caballo Dam; $B$, Rio Grande below Leasburg; and $C$, Rio Grande at El Paso

6. Cumulative $\Delta$ Salt Load changes by nonrelease and release seasons within calendar years for $A$, the Rincon Valley, and $B$, the Mesilla Valley in the Rio Grande Project area, January 1, 2009, through September 30, 2013 
7. Example of seasonal and annual grouping of groundwater data using surfacewater discharge-defined release/nonrelease seasons in the Rio Grande Project area

8. Boxplots of seasonally grouped data showing overall and seasonal trends for depth to groundwater and specific conductance data for each shallow well in the Rio Grande Project area, New Mexico and Texas

9. Spatial distribution of low-flow seepage results and nonrelease groundwaterlevel trends in the Mesilla Valley, Rio Grande Project area, New Mexico and Texas, 2009-13

\section{Tables}

1. Construction data for shallow alluvial wells listed upgradient to downgradient in the Rincon and Mesilla Valleys, in the Rio Grande Project area, New Mexico and Texas

2. Number of days of discharge greater than the release season threshold value $(500,000$ cubic meters per day at the streamgage below Caballo Dam) at each streamgage, 2009-13

3. Annual mean and seasonal mean depth to groundwater and specificconductance data from wells in the Rincon Valley in the Rio Grande Project area, New Mexico and Texas, 2009-13

4. Annual mean and seasonal mean depth to groundwater and specificconductance data from wells in the Mesilla Valley in the Rio Grande Project area, New Mexico and Texas, 2009-13

5. Seasonal Mann-Kendall tau values for all continuous groundwater data in the Rincon and Mesilla Valleys in the Rio Grande Project area, New Mexico and Texas, 2009-13

6. Mann-Kendall tau values for daily depth to groundwater data from shallow wells in the Mesilla Valley for continuous nonrelease seasons (from the end of the previous year release season to the current year release season), 2009-13

7. Annual driver and response variables from various sources for the Rincon and Mesilla Valleys, in the Rio Grande Project area, New Mexico and Texas, 2009-13

8. Pearson's $r$ values between driver and response variables in the Rincon and Mesilla Valleys, in the Rio Grande Project area, New Mexico and Texas, 2009-13 


\section{Conversion Factors}

Inch/Pound to International System of Units

\begin{tabular}{|c|c|c|}
\hline Multiply & By & To obtain \\
\hline \multicolumn{3}{|c|}{ Length } \\
\hline inch (in.) & 2.54 & centimeter $(\mathrm{cm})$ \\
\hline foot $(\mathrm{ft})$ & 0.3048 & meter $(\mathrm{m})$ \\
\hline mile (mi) & 1.609 & kilometer (km) \\
\hline \multicolumn{3}{|c|}{ Area } \\
\hline acre & 4,047 & square meter $\left(\mathrm{m}^{2}\right)$ \\
\hline acre & 0.4047 & hectare (ha) \\
\hline acre & 0.4047 & square hectometer $\left(\mathrm{hm}^{2}\right)$ \\
\hline acre & 0.004047 & square kilometer $\left(\mathrm{km}^{2}\right)$ \\
\hline \multicolumn{3}{|c|}{ Volume } \\
\hline cubic foot $\left(\mathrm{ft}^{3}\right)$ & 28.32 & cubic decimeter $\left(\mathrm{dm}^{3}\right)$ \\
\hline liter $(\mathrm{L})$ & 1,000 & cubic meter $\left(\mathrm{m}^{3}\right)$ \\
\hline acre-foot (acre-ft) & 1,233 & cubic meter $\left(\mathrm{m}^{3}\right)$ \\
\hline acre-foot (acre-ft) & 0.001233 & cubic hectometer $\left(\mathrm{hm}^{3}\right)$ \\
\hline \multicolumn{3}{|c|}{ Flow rate } \\
\hline acre-foot per year (acre-ft/yr) & 1,233 & cubic meter per year $\left(\mathrm{m}^{3} / \mathrm{yr}\right)$ \\
\hline acre-foot per year (acre-ft/yr) & 0.001233 & cubic hectometer per year $\left(\mathrm{hm}^{3} / \mathrm{yr}\right)$ \\
\hline cubic foot per second $\left(\mathrm{ft}^{3} / \mathrm{s}\right)$ & 0.02832 & cubic meter per second $\left(\mathrm{m}^{3} / \mathrm{s}\right)$ \\
\hline \multicolumn{3}{|c|}{ Mass } \\
\hline ton, short $(2,000 \mathrm{lb})$ & $907,200,000$ & milligram (mg) \\
\hline ton per day (ton/d) & 0.9072 & metric ton per day \\
\hline \multicolumn{3}{|c|}{ Transmissivity* } \\
\hline foot squared per day $\left(\mathrm{ft}^{2} / \mathrm{d}\right)$ & 0.09290 & meter squared per day $\left(\mathrm{m}^{2} / \mathrm{d}\right)$ \\
\hline
\end{tabular}

International System of Units to Inch/Pound

\begin{tabular}{lcl}
\hline \multicolumn{1}{c}{ Multiply } & By & \multicolumn{1}{c}{ To obtain } \\
\hline cubic meter per second $\left(\mathrm{m}^{3} / \mathrm{s}\right)$ & Flow rate & \\
cubic meter per year $\left(\mathrm{m}^{3} / \mathrm{yr}\right)$ & 70.07 & acre-foot per day $(\mathrm{acre}-\mathrm{ft} / \mathrm{d})$ \\
cubic meter per day $\left(\mathrm{m}^{3} / \mathrm{d}\right)$ & 0.000811 & acre-foot per year $(\mathrm{acre}-\mathrm{ft} / \mathrm{yr})$ \\
cubic meter per day $\left(\mathrm{m}^{3} / \mathrm{d}\right)$ & 35.31 & cubic foot per day $(\mathrm{ft} / \mathrm{d})$ \\
cubic meter per second $\left(\mathrm{m}^{3} / \mathrm{s}\right)$ & 264.2 & gallon per day $(\mathrm{gal} / \mathrm{d})$ \\
\hline
\end{tabular}

Temperature in degrees Celsius $\left({ }^{\circ} \mathrm{C}\right)$ may be converted to degrees Fahrenheit $\left({ }^{\circ} \mathrm{F}\right)$ as ${ }^{\circ} \mathrm{F}=\left(1.8 \times{ }^{\circ} \mathrm{C}\right)+32$. 


\section{Data}

Vertical coordinate information is referenced to the North American Vertical Datum of 1988 (NAD 88).

Horizontal coordinate information is referenced to the North American Datum of 1983 (NAD 83).

\section{Supplemental Information}

Transmissivity: The standard unit for transmissivity is cubic foot per day per square foot times foot of aquifer thickness $\left[\left(\mathrm{ft}^{3} / \mathrm{d}\right) / \mathrm{ft}^{2}\right] \mathrm{ft}$. In this report, the mathematically reduced form, foot squared per day $\left(\mathrm{ft}^{2} / \mathrm{d}\right)$, is used for convenience.

Specific conductance is given in microsiemens per centimeter at 25 degrees Celsius $(\mu \mathrm{S} / \mathrm{cm}$ at $\left.25^{\circ} \mathrm{C}\right)$.

Concentrations of chemical constituents in water are given in either milligrams per liter $(\mathrm{mg} / \mathrm{L})$ or micrograms per liter $(\mu \mathrm{g} / \mathrm{L})$.

Dissolved-solids loads were calculated by first converting concentration data from milligrams per liter $(\mathrm{mg} / \mathrm{L})$ to milligrams per cubic meter $\left(\mathrm{mg} / \mathrm{m}^{3}\right)$.

\section{Abbreviations}

$\begin{array}{ll}\text { DS } & \text { dissolved solids } \\ \text { NWIS } & \text { National Water Information System } \\ \text { RG-CB } & \text { Rio Grande below Caballo Dam USGS Station ID: 08362500 } \\ \text { RG-EP } & \text { Rio Grande at El Paso USGS Station ID: 08363510 } \\ \text { RG-LB } & \text { Rio Grande below Leasburg Dam at Fort Selden USGS Station ID: } 08364000 \\ \text { SC } & \text { specific conductance } \\ \text { USGS } & \text { U.S. Geological Survey }\end{array}$




\title{
Variability of Surface-Water Quantity and Quality and Shallow Groundwater Levels and Quality Within the Rio Grande Project Area, New Mexico and Texas, 2009-13
}

\author{
By Jessica M. Driscoll and Lauren R. Sherson
}

\section{Abstract}

Drought conditions during the study period of January 1 , 2009 , to September 30, 2013, caused a reduction in surfacewater releases from water-supply storage infrastructure of the Rio Grande Project, which led to changes in surfacewater and groundwater (conjunctive) use in downstream agricultural alluvial valleys. Surface water and groundwater in the agriculturally dominated alluvial Rincon and Mesilla Valleys were investigated in this study to measure the influence of drought and subsequent change in conjunctive water use on quantity and quality of these water resources. In 2013, the U.S. Geological Survey, in cooperation with the New Mexico Environment Department and the New Mexico Interstate Stream Commission, began a study to (1) calculate dissolved-solids loads over the study period at streamgages in the study area where data are available, (2) assess the temporal variability of dissolved-solids loads at and between each streamgage where data are available, and (3) relate the spatiotemporal variability of shallow groundwater data (groundwater levels and quality) within the alluvial valleys of the study area to spatiotemporal variability of surface-water data over the study period. This assessment included the calculation of surface-water dissolved-solids loads at streamgages as well as a mass-balance approach to measure the change in salt load between these streamgages. Bimodal surface-water discharge data led to a temporallydynamic volumetric definition of release and nonrelease seasons. Continuous surface-water discharge and waterquality data from three streamgages on the Rio Grande were used to calculate daily dissolved-solids loads over the study period, and the results were aggregated annually and seasonally. Results show the majority of dissolved-solids loading occurs during release season; however, decreased duration of the release season over the 5-year study period has resulted in a decrease of the total annual loads at each streamgage. Calculation of the change of salt loads using a mass-balance approach was applied between streamgages. Results from these calculations suggest differing responses to releases in the Rincon and Mesilla Valleys over the period of study; there is a decreasing sink of salt in the Rincon Valley whereas there is an increasing sink of salt in the Mesilla Valley. Daily groundwater-level and water-quality data from shallow wells within the two alluvial valleys show spatial heterogeneity of water quality over the study period. Mass-balance salt-loading trends during the study period are similar to previous trends during the 1950s drought as well as a wet period in the $1980 \mathrm{~s}$. The similarity of salt-loading trends from the 1950s, 1980s, and 2000s independent of the climate indicates salt loading in this hydrologic setting may be driven by water-use practices rather than a single climatic variable.

\section{Introduction}

The Rio Grande Compact (New Mexico State Annual $\S$ 75-34-3 [1953], Act of May 31, 1939, ch. 155, 53 Stat. 785) apportions the waters of the Rio Grande above Fort Quitman, Texas, among the States of Colorado, New Mexico, and Texas. The Rio Grande Project, consisting of Elephant Butte and Caballo Reservoirs (fig. 1), 6 diversion dams, 141 miles of canals, 462 miles of laterals, 457 miles of drains, and a hydroelectric plant, was developed between 1906 and 1952 (Autobee, 1994) to supply surface water for irrigation to lands in New Mexico and Texas. The Elephant Butte Irrigation District and El Paso County Water Improvement District No. 1 operate and maintain the Rio Grande Project system of irrigation canals and laterals below Caballo Dam, which delivers irrigation water to 90,640 acres of land within New Mexico and 68,000 acres within Texas (Bureau of Reclamation, 2008). The Bureau of Reclamation manages releases from Elephant Butte Reservoir and Caballo Dam.

Historically, as well as within the timeframe of this study, drought conditions have resulted in reduced water supply for storage at Elephant Butte Reservoir, which supplies surface water for the Rio Grande Project (Bureau of Reclamation, 2009). Caballo Reservoir water releases between 2009 and 2013 were reduced and (or) delayed, as observed in daily discharge measurements at the U.S. Geological Survey 


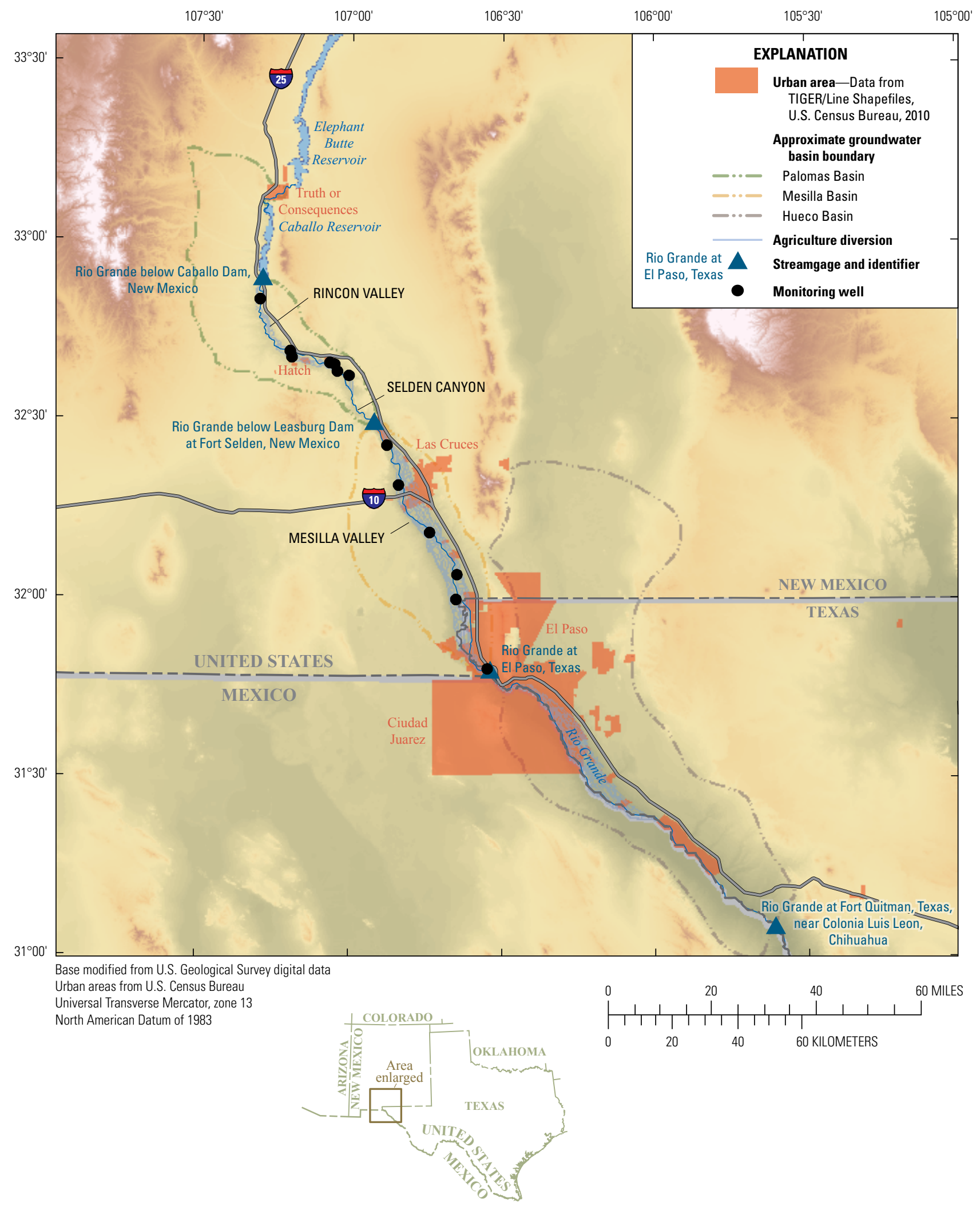

Figure 1. Location of the Rio Grande Project area and groundwater basins, New Mexico and Texas. 
(USGS) Rio Grande below Caballo Dam streamgage (McKean and others, 2014). Reduced surface-water supply can lead to agricultural practice adaptation, including practices that reduce water demand (such as fallowing fields and crop rotation to crops with lower water needs) and practices that utilize alternative sources of water (such as pumping groundwater). Previous periods of reduced surface-water supply have resulted in increased groundwater pumpage in the Rincon and Mesilla Valleys to maintain the growing season from March to October (Wilson and others, 1981; Moyer and others, 2013). Groundwater use for supplemental irrigation within the Rincon and Mesilla Valleys ranged from 130,540 acre-feet per year (acre-ft/yr) in 2009 to 286,050 acre-ft/yr in 2013 (R.J. Serrano, New Mexico Office of the State Engineer, unpub. data, 2014).

Concentrations of dissolved solids increase through concentrative or additive processes in the study area. Concentrative processes remove water and leave dissolved solids, which results in an increased concentration in the remaining water. Evaporation and transpiration are concentrative processes that increase dissolved-solids concentrations. Additive processes transport additional dissolved solids into a riverine system that can be categorized into three groups: (1) surficial salts, (2) inflow of saline groundwater, and (3) anthropogenic salt inputs (Phillips and others, 2003; Anning and others, 2007; Hogan and others, 2007). Surficial salts are delivered to riverine systems through precipitation and subsequent dissolution of accumulated salt in near-surface soils. Saline groundwater contains elevated concentrations of dissolved solids that originate from geothermal or nongeothermal sources. Saline groundwater can be derived from the dissolution of evaporite deposits such as ancestral playa beds (Hibbs and Merino, 2007), gypsum and calcite (Witcher and others, 2004), sedimentary brines of connate or diagenetic origin (Phillips and others, 2003; Witcher and others, 2004; Hogan and others, 2007), or geothermal processes (Bothern, 2003; Witcher and others, 2004). Anthropogenic salt inputs can be derived from a number of sources in agricultural, residential, and industrial areas. Examples of anthropogenic sources include fertilizers, road salt, and industrial processes (Bothern, 2003; Szynkiewicz and others, 2011). These salts are often delivered to riverine systems through irrigation runoff, effluent from municipal wastewater treatment, or effluent from industrial water treatment.

The increase of dissolved-solids concentration from approximately 40 milligrams per liter $(\mathrm{mg} / \mathrm{L})$ in the headwaters of the Rio Grande to $500-1,500 \mathrm{mg} / \mathrm{L}$ in the Rio Grande at El Paso has been attributed to upwelling of deep saline groundwater (Phillips and others, 2003; Hogan and others, 2007) and input of drain-intercepted evapoconcentrated irrigation waters (Wilson and others, 1981; Anderholm, 2002; Moore and others, 2008). The alluvial agricultural valleys downstream from Elephant Butte and Caballo Reservoirs along the Rio Grande are complex, highly managed systems. The extent to which deep, saline groundwater and agricultural practices degrade water quality in this system is of critical interest to water managers and is the focus of many previous studies in the area (Phillips and others, 2003; Hogan and others, 2007; Szynkiewicz and others, 2011).

During the last decade, drought conditions as well as changes in the conjunctive use of surface water and groundwater have resulted in changes in surface-water flows and groundwater levels. These hydrologic changes may result in changes in the concentrations of dissolved solids in surface water and groundwater in the valleys, which could adversely affect municipal, agricultural, and environmental uses. In 2013, the U.S. Geological Survey, in cooperation with the New Mexico Environment Department and the New Mexico Interstate Stream Commission, began a study to (1) calculate dissolved-solids loads over the study period at streamgages in the study area where data are available, (2) assess the temporal variability of dissolved-solids loads at and between each streamgage where data are available, and (3) relate the spatiotemporal variability of shallow groundwater data (groundwater levels and quality) within the alluvial valleys of the study area to the spatiotemporal variability surface-water data over the study period.

\section{Purpose and Scope}

This report describes the spatiotemporal variability of surface-water and shallow groundwater data in the Rincon and Mesilla Valleys within the Rio Grande Project area (fig. 2). Surface-water quantity and quality in the Rio Grande from January 1, 2009, to September 30, 2013, are used to assess temporal variability of dissolved-solids loads using volumetric, discharge-defined seasons. Three out of four streamgages on the Rio Grande were selected for analysis. Adequate continuous specific-conductance data were available at three locations in the study area: the Rio Grande below Caballo Dam, N. Mex. (USGS Station ID: 08362500, RG-CB), Rio Grande below Leasburg Dam at Fort Selden, N. Mex. (USGS Station ID: 08363510, RG-LB), and Rio Grande at El Paso, Tex. (USGS Station ID: 08364000, RG-EP); data were inadequate at the Rio Grande at Fort Quitman streamgage because of large gaps between measurements. Adequate continuous discharge data were available at RG-CB, the Leasburg River Cable by the Elephant Butte Irrigation District, which were used for RG-LB, and a colocated streamgage reported by the U.S. Bureau of Reclamation and provided by the International Boundary and Water Commission for RG-EP; data were inadequate at the Rio Grande at Fort Quitman streamgage because of large gaps between measurements. All surfacewater specific-conductance (SC) and discharge data used in this report are included in USGS Data Series 884 (McKean and others, 2014). Data from a network of 13 shallow groundwater wells with in-situ groundwater level and SC probes in the Rincon and Mesilla Valleys were used to assess shallow groundwater from January 1, 2009, to September 30,2013 . These groundwater data were grouped in the 


\section{Rincon Valley}

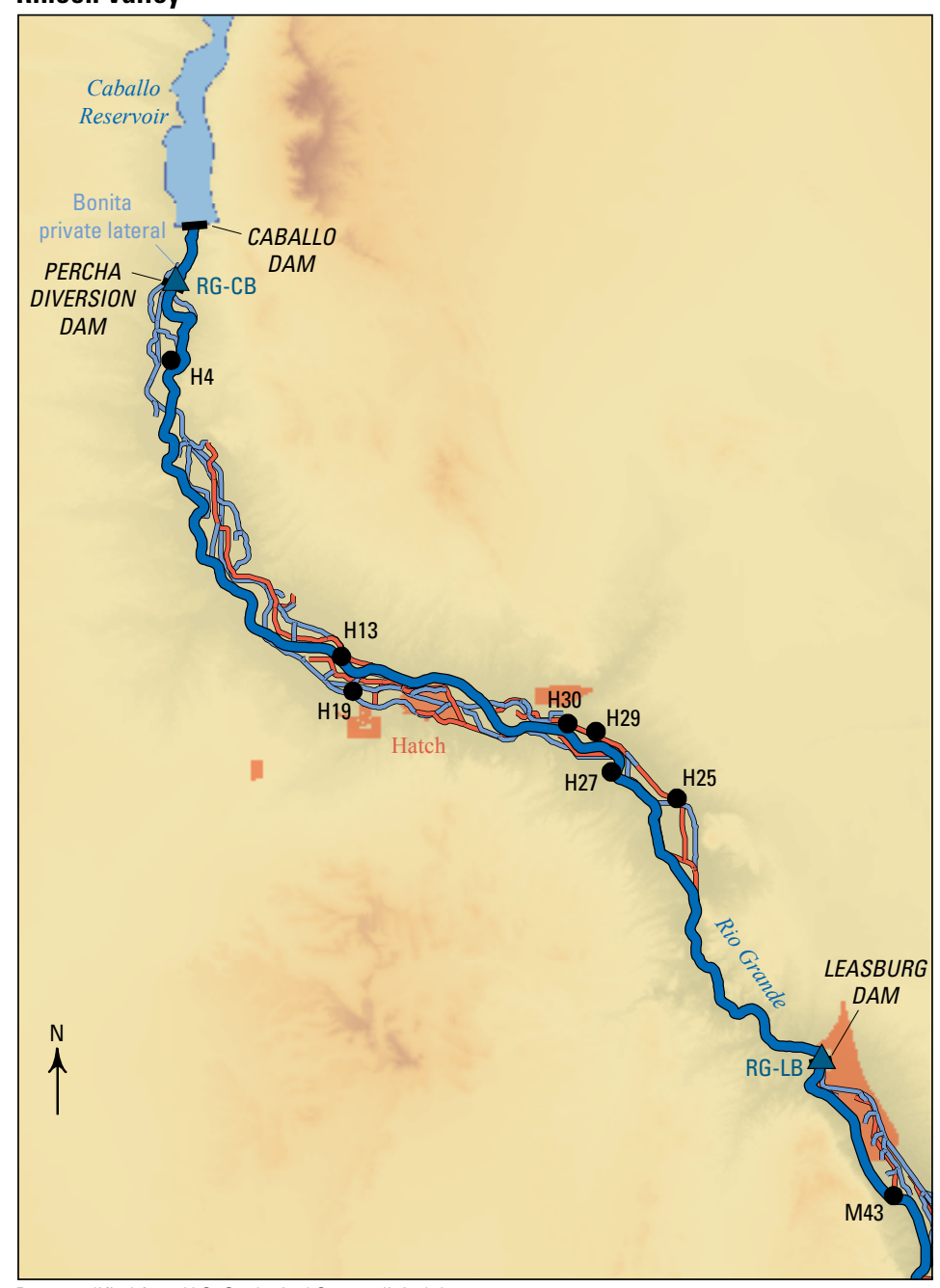

Base modified from U.S. Geological Survey digital data Universal Transverse Mercator, zone 13 North American Datum of 1983

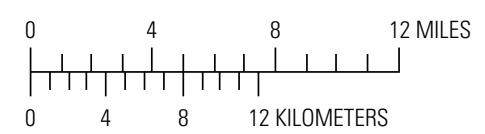

\section{Mesilla Valley}

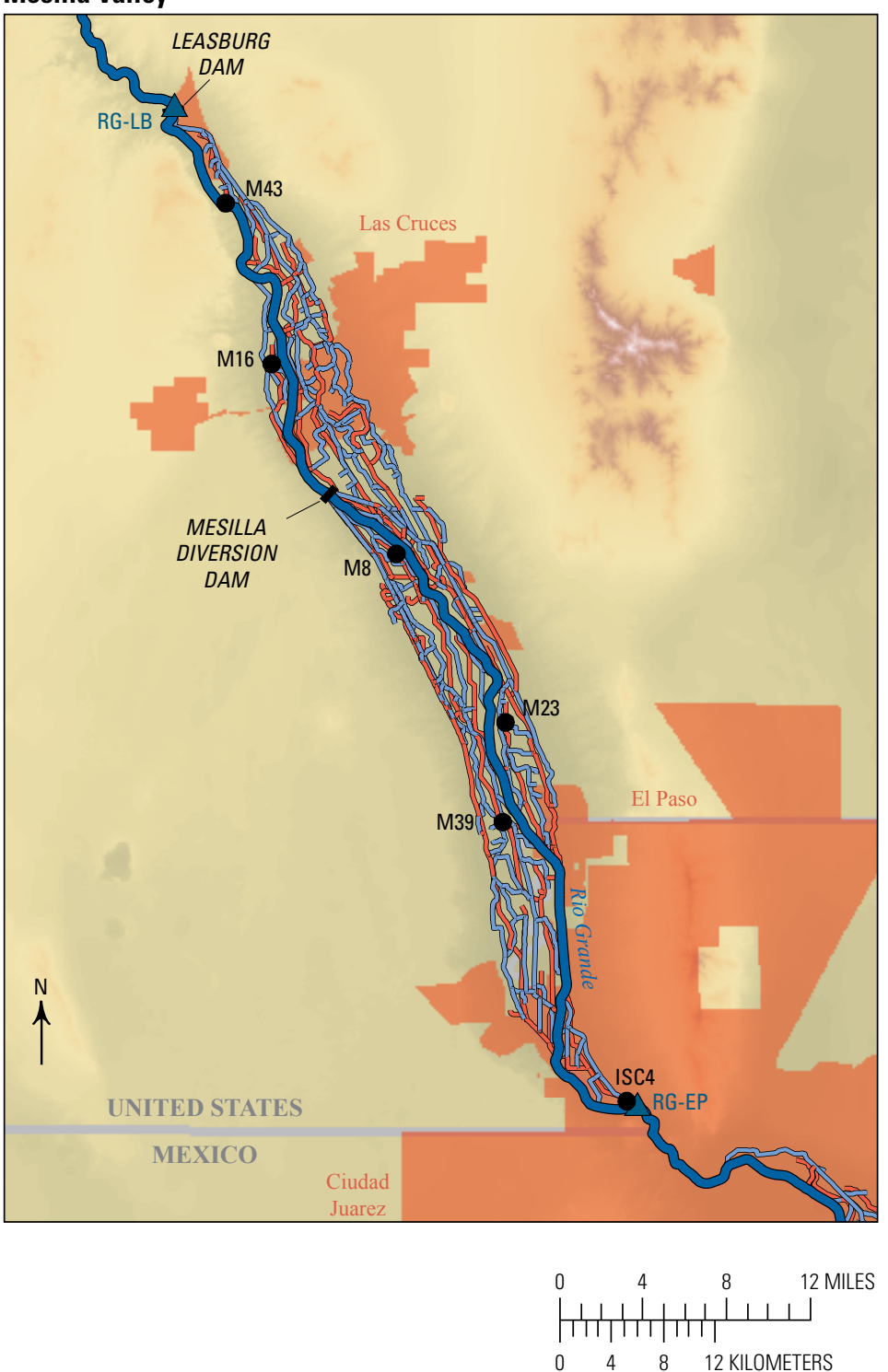

EXPLANATION

Urban area-Data from TIGER/Line Shapefiles, U.S. Census Bureau,

2010

Rio Grande

Canal or lateral—Data from Middle Rio Grand Conservancy District (MRGCD), 2012

rain or wasteway-Dat
from MRGCD, 2012

RG-LB Streamgage and identifier

H29 Monitoring well and identifier

Streamgage, in downstream order

RG-CB Rio Grande below Caballo Dam, New Mexico

RG-LB Rio Grande below Leasburg Dam at Fort Selden, New Mexico

RG-EP Rio Grande at El Paso Texas

Figure 2. Location of the Rincon and Mesilla Valleys within the Rio Grande Project area, New Mexico and Texas. 
same surface-water-defined seasons to assess the seasonto-season and overall study period variability. The results from previous studies, which quantified low-flow seepage within the Mesilla Valley, were also compared to trends in shallow groundwater wells (Crilley and others, 2013). Annual summary statistics of calculated dissolved-solids loads were compared with potential climate and anthropogenic driver variables to assess possible correlation. Correlation between climatic and anthropogenic driver variables and surface-water and groundwater-quality data may show a relation between conjunctive-use management of water resources and water quality in the lower Rio Grande Basin.

\section{Description of Study Area}

The Rio Grande flows south from its headwaters in southwestern Colorado through New Mexico and into Texas, forming the international boundary between Texas and Mexico below El Paso, Tex., and continuing to the Gulf of Mexico, with a total length of 1,896 miles. The study area encompasses southern New Mexico and far west Texas along the Rio Grande below RG-CB (fig. 1). There are three groundwater basins along the Rio Grande below Caballo Reservoir and above Fort Quitman: the Palomas, Mesilla, and the Hueco. The Palomas and Mesilla Basins are included in the analysis for this study; the Hueco Basin could not be included in this assessment because of a scarcity of water-quality data for the study period. The addition of continuous water-quality data collection at Fort Quitman would allow for analysis of the Hueco Basin to be included in future assessments.

Surface-water flow in the Rio Grande is controlled by releases from Elephant Butte and Caballo Reservoirs. During the summer growing seasons, surface-water flow in the Rio Grande in the study area is controlled primarily by releases from the Rio Grande Project's Caballo Dam (release season). During the winter seasons within the study period, when there were no releases from the Rio Grande Project dams (nonrelease season), the riverbed was often dry for significant stretches within the study area. There are a few minor tributary drainages to the Rio Grande within the study area, but these tributaries sustain only ephemeral surface-water flow following large precipitation events. The only perennial tributaries to the Rio Grande in the study area are manmade agricultural drains (Anderholm, 2002).

The alluvial Rincon and Mesilla Valleys are located within the Palomas and Mesilla Basins, respectively (figs. 1 and 2). In this study, the Rincon Valley is bounded upstream by $\mathrm{RG}-\mathrm{CB}$ and downstream by RG-LB. The Mesilla Valley is bounded upstream by RG-LB and downstream by RG-EP. Agriculture, predominately irrigated through gravity-fed diversions from the Rio Grande, is the dominant land use in the Rincon and Mesilla Valleys (Wilson and others, 1981). Crops in the Rincon and Mesilla Valleys include row crops (such as chiles, cotton, onions, and other vegetables) and pecan orchards. Fields are irrigated by means of the Rio
Grande Project infrastructure in the irrigation districts, using water released from Caballo Reservoir at Caballo Dam.

A series of canals move irrigation water from the point of diversion on the Rio Grande to individual fields in the Rincon and Mesilla Valleys. Surface water is diverted from the river through three diversion dams to canals: the Percha Diversion Dam in the Rincon Valley and the Leasburg Diversion Dam (Leasburg Dam) and the Mesilla Diversion Dam in the Mesilla Valley (fig. 2). Most canals, which convey the water through the valleys, are constructed above the level of the fields so water can be diverted into the fields by gravity. Water infiltrates directly from these canals to the subsurface because the canals are above the water table and are unlined; part of this leakage recharges shallow groundwater (Anderholm, 2002). Leakage of water from irrigation canals to shallow groundwater, evaporation from canal surfaces, and transpiration from plants along these canals, which together are referred to as canal losses, have historically (from 1930 to 1975) accounted for a quarter to more than a half of the diverted water in the Rincon and Mesilla Valleys (Conover, 1954; Wilson and others, 1981). Groundwater exchange with the Rio Grande, irrigation canals, irrigated fields, drains, and irrigation wells creates many localized flow systems, generally from the canals to the drains, during the irrigation season.

The hydrogeology of the Palomas, Mesilla, and Hueco Basins has been the subject of many reports (Wilson and others, 1981; Anderholm, 2002; Phillips and others, 2003; Hawley and Kennedy, 2004; Witcher and others, 2004; Hogan and others, 2007; Eastoe and others, 2008; Moore and others, 2008; Hawley and others, 2009). The Rio Grande Valley alluvium deposits of Quaternary age and the underlying Santa Fe Group of Tertiary age are the most relevant subsurface units to surface-water/groundwater exchange. A crosscutting block fault at Selden Canyon between the Rincon and Mesilla Valleys forces groundwater upwards to the near surface (Conover, 1954). This physical boundary occurs just upstream from RG-LB and separates the Palomas Basin from the Mesilla Basin (fig. 1). There is also a physical geologic boundary near the New Mexico and Texas border and upgradient from RG-EP that directs water upwards to the near surface (Wilson and others, 1981).

In the Rincon Valley, the Quaternary alluvial-fill deposits are generally less than 80 feet (ft) thick (Conover, 1954) and consist of gravel, sand, silt, and clay-sized sediment. The lower 30-40 ft of the valley-fill deposits are relatively coarse grained; above this coarse-grained material there is considerable lateral variation in grain size and sorting of the deposits (Anderholm, 2002). The Santa Fe Group underlying the Rincon Valley alluvium consists of clay-sized material and does not yield substantial quantities of water (Anderholm, 2002).

The hydraulic property of groundwater transmissivity (the rate at which water flows through the subsurface) has been estimated using the measurement of the specific capacity (the pumping yield divided by the drawdown) in previous investigations, and these transmissivity values were compared 
for the Rincon and Mesilla Valleys. Transmissivity of the alluvial-fill deposits in the Rincon Valley estimated from specific capacities, averages 9,200 feet squared per day $\left(\mathrm{ft}^{2} / \mathrm{d}\right)$ (Wilson and others, 1981). There is a greater volume of saturated sediment in the Mesilla Valley relative to the Rincon Valley, consisting of flood-plain alluvium and the underlying fluvial deposits of the Santa Fe Group, which has been described as a leaky confined aquifer as a result of interbedded impermeable clay layers (Wilson and others, 1981; Hawley and Kennedy, 2004). Transmissivity of the upper $1,000 \mathrm{ft}$ of saturated thickness (Santa Fe Group deposits and Rio Grande Valley alluvium) in the Mesilla Valley is greater than in the Rincon Valley, with values ranging from 10,000 to 40,000 $\mathrm{ft}^{2} / \mathrm{d}$ as estimated from specific capacities (Wilson and others, 1981).

While most surface water used for irrigation in the Rincon Valley is diverted from the Rio Grande into the agricultural diversion system at the Percha Diversion Dam, a small amount of water is also diverted to the Bonita private lateral, which is located upstream from RG-CB (fig. 2). The Bonita private lateral supplies water to fields in the northern part of the Rincon Valley. The diversion to the Bonita private lateral is generally less than 0.5 percent of flow measured at RG-CB (Bureau of Reclamation, 2013a). The water diverted to the Bonita private lateral is not recorded at $\mathrm{RG}-\mathrm{CB}$, though flow returns back to the river and contributes to the volume and water quality measured at RG-LB. The Bonita private lateral was not included into the salt-loading calculations for this study. This may result in approximately 0.5 percent underestimation of flow, and therefore underestimation of salt load at RG-CB during the release season.

\section{Approach}

Water-quality, discharge, and groundwater-level data include a variety of sources, locations, and timing of data collection. These data are described below by data type (such as surface water, groundwater, and seepage), with each section describing the data collection location and frequency. Data used for analysis, including methods for collection and analysis, are collated in USGS Data Series 884 (McKean and others, 2014) and are available in the USGS National Water Information System (NWIS) database (U.S. Geological Survey, 2015). This assessment covers the Rincon and Mesilla Valleys of southern New Mexico. Consistent water-quality data were not available downstream from the Mesilla Valley to the Fort Quitman streamgage; therefore, the Hueco Basin (fig. 1) was not included in this assessment.

\section{Surface Water}

Continuous daily data (discharge and specific conductance) were evaluated at three streamgages along the Rio Grande in the study area: RG-CB, RG-LB, and
RG- EP (fig. 1). The measured daily surface-water specificconductance (SC) values, measured in microseimen per centimeter at 25 degrees Celsius $(\mu \mathrm{S} / \mathrm{cm})$ were converted to dissolved-solids (DS) concentrations (which are used as an approximation of salinity) through a linear conversion:

$$
S C(\mu S / \mathrm{cm}) \times \text { Conversion Factor }=D S(m g / L)
$$

This direct SC/DS relation has been used in previous studies in the area (Witcher and others, 2004; Moyer and others, 2013). The conversion factor was calculated using discrete Rio Grande surface-water-quality data from 2009 to 2013 (McKean and others, 2014), when DS and SC parameters were collected together. The DS concentrations measured from drying at 180 degrees Celsius (USGS NWIS parameter code 70300) and the unfiltered SC values (USGS NWIS parameter code 00095) from surface-water samples collected between 2009 and 2013 (number of data values [n] $=178$, table 5 from McKean and others, 2014) have a strong linear correlation (coefficient of determination $\left[\mathrm{R}^{2}\right]=0.9895$ ) (fig. 3).

Data from January 1, 2009, through September 30, 2013 (the study period) from McKean and others (2014) were used for this study. The time period of the study, January 1, 2009, to September 30, 2013, was chosen because the density of daily data collected over this time frame was greatest at each of the three streamgages; however, there are several gaps in these continuous daily water-quality data. Data gaps are caused by instrument failure because of fouling or lack of flow in the river. These gaps had to be filled to calculate daily DS loads. Gaps in water-quality data were addressed through linear interpolation of data to fill in days without data over the study period. Many of the days with no water-quality data occurred when there also was no flow at the streamgage, and therefore the resulting load value was zero. Water-quality data collected at RG-CB and RG-LB were not reported past July 13, 2013, and August 19, 2013, respectively (McKean and others, 2014). These dates occur prior to the end of the September 30, 2013, study period, and therefore no linear interpolation after this last day of measurement was possible. The total days with data used for load calculations in 2013 at the streamgages were 194, 231, and 273 days at RG-CB, RG-LB, and RG-EP, respectively. Dissolved-solid load calculations and analysis for streamgages in the study area were completed from January 1, 2009, to September 30, 2013.

The slope of the linear relation between SC and DS is 0.6518 for data collected from 2009 to 2013 (fig. 3), and this slope value was used as the conversion factor for SC to DS (eq. 1) for this study. This conversion factor is slightly less than the one derived from the 1934 to 1963 data (0.66), which was used for annual mass-balance calculations by Williams (2001) and Witcher and others (2004). Dissolved solids is a cumulative measure of solutes (salts) in a given water and does not account for the relative distribution of these salts (such as calcium, magnesium, sodium, potassium, sulfate, chloride, and bicarbonate) contributing to DS. A change in the relation of SC and DS over time may reflect a change in 


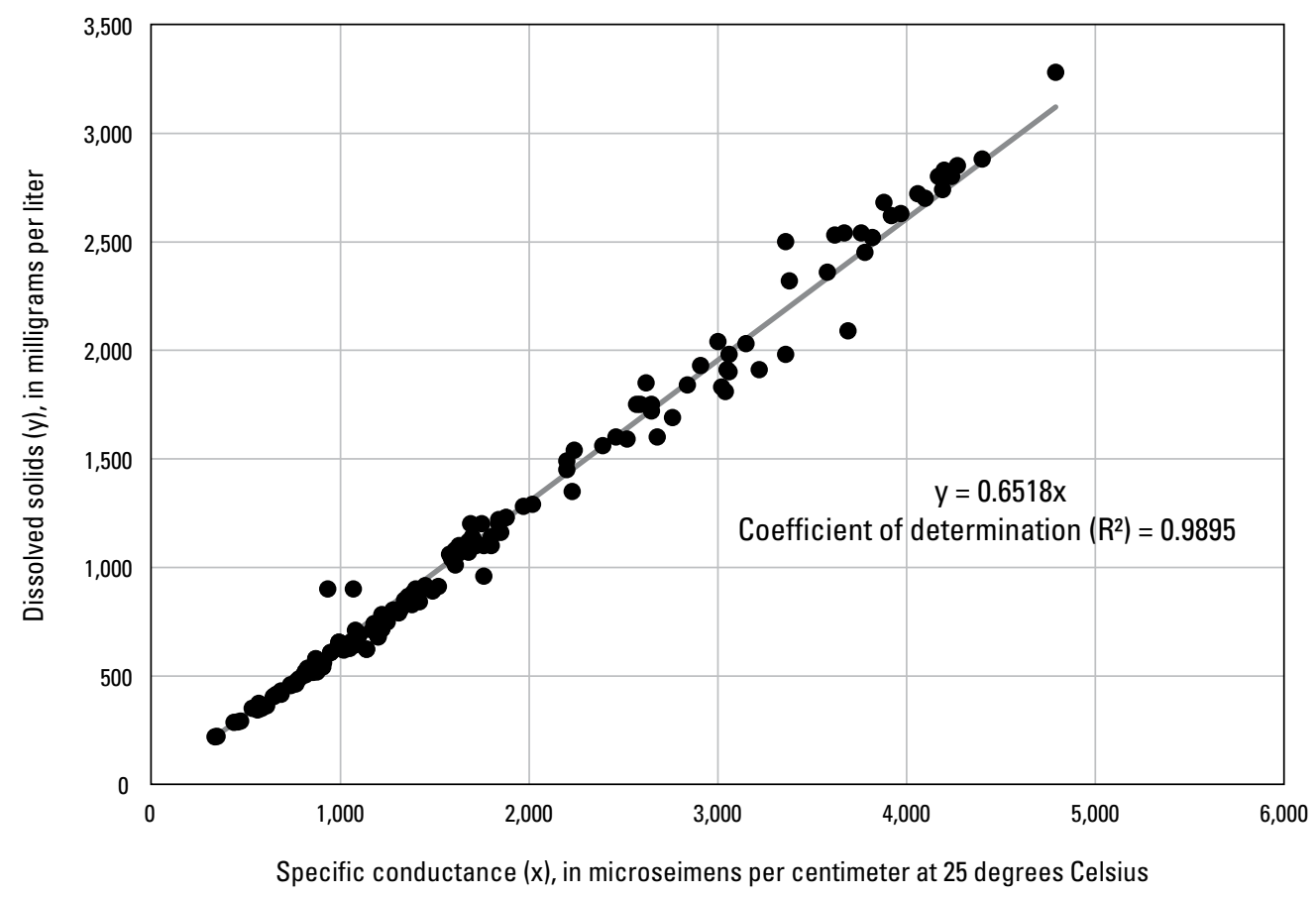

Figure 3. Discrete specific-conductance and dissolved-solids data from surface-water samples collected in the Rio Grande Project area, New Mexico and Texas, 2009-13.

contributing salts (and therefore sources) over time. Some salts, such as sulfate, may have both anthropogenic (fertilizer) and geologic (weathering products) sources in the study area (Szynkiewicz and others, 2011) and have a lower conversion factor relation to SC (eq. 1) than was found in the study area surface-water SC/DS relation (fig. 3) for the study period. The effects of long-term variability in the SC/DS relation are negligible because the SC/DS relation derived by this study uses surface-water data specific to the study period.

\section{Groundwater}

Groundwater data were collected using continuous in-situ probes in 13 wells; 7 (from north to south, respectively: H4, $\mathrm{H} 13, \mathrm{H} 19, \mathrm{H} 30, \mathrm{H} 29, \mathrm{H} 27$, and H25) in the Rincon Valley and 6 (from north to south, respectively: M43, M16, M8, M23, M39, and ISC4) in the Mesilla Valley (fig. 2). These wells are shallow; total casing depth does not exceed $35 \mathrm{ft}$ for any well, and screened interval depths range from approximately 7 to $24 \mathrm{ft}$ in the Rincon Valley and approximately 4 to $25 \mathrm{ft}$ in the Mesilla Valley (table 1). Wells in the Rincon Valley were constructed in March 1994 as part of the USGS National Water-Quality Assessment Program, though the original H13 went dry and was redrilled by the USGS in 2005. Aquifer unit (alluvium) and material type (sand and silt) were recorded in the USGS well-installation records for wells located in the Rincon Valley. Well records do not exist in USGS wellinstallation record (USGS NWIS Ground-Water Site-Inventory database) for the Mesilla Valley; however, a well-installation summary report made available by the New Mexico Interstate Stream Commission (Ennis, 2009) shows the wells in the Mesilla Valley, installed in January and February of 2009, were completed in alluvial sand and silt.

Specific conductance and groundwater levels were measured at each of these 13 wells using in-situ multiparameter probes calibrated and maintained according to standard USGS protocols (Wagner and others, 2006). Continuous daily-data records began in 2009 (after well completion in the Mesilla Valley) and are currently (2016) ongoing. High transmissivity values of the alluvial deposits (Wilson and others, 1981) into which these wells are completed (table 1), and daily variability in water-level and $\mathrm{SC}$ data, have led to the assumption that in-situ probes in these shallow wells are measuring water representative of the shallow aquifer at these points, and not stagnant well water.

In addition to continuous $\mathrm{SC}$ data for the 13 shallow groundwater wells, discrete groundwater SC data were collected independently from 79 wells within the Palomas and Mesilla Basins from 2008 to 2013 (presented in McKean and others, 2014). Data were available for only one sample date for 48 of these wells and for more than one sample date for 31 of these wells, ranging from 2 to 6 sample dates from 2008 to 2013. Sample dates were generally not at the same time each year in these wells, making the analysis of SC data difficult given the high annual variability in hydrologic conditions observed in the study area based on continuous daily data. 
Table 1. Construction data for shallow alluvial wells listed upgradient to downgradient in the Rincon and Mesilla Valleys, in the Rio Grande Project area, New Mexico and Texas.

[USGS, U.S. Geological Survey; ID, identifier; YYYYMMDD, year, month, day; w/, with]

\begin{tabular}{|c|c|c|c|c|c|c|c|c|c|c|c|c|}
\hline USGS site ID & Well ID & $\begin{array}{c}\text { Date } \\
\text { completed } \\
\text { (YYYYMMDD) }\end{array}$ & $\begin{array}{l}\text { Method of } \\
\text { construction }\end{array}$ & $\begin{array}{l}\text { Diameter } \\
\text { of hole } \\
\text { (inches) }\end{array}$ & $\begin{array}{l}\text { Casing } \\
\text { diameter } \\
\text { (inches) }\end{array}$ & $\begin{array}{l}\text { Depth to } \\
\text { bottom } \\
\text { of casing } \\
\text { (feet) }\end{array}$ & $\begin{array}{l}\text { Depth to } \\
\text { bottom } \\
\text { of seal } \\
\text { (feet) }\end{array}$ & $\begin{array}{l}\text { Type of } \\
\text { surface } \\
\text { seal }\end{array}$ & $\begin{array}{c}\text { Depth } \\
\text { to top of } \\
\text { screened } \\
\text { interval } \\
\text { (feet) }\end{array}$ & $\begin{array}{c}\text { Depth to } \\
\text { bottom of } \\
\text { screened } \\
\text { interval } \\
\text { (feet) }\end{array}$ & $\begin{array}{l}\text { Length of } \\
\text { screened } \\
\text { interval } \\
\text { (feet) }\end{array}$ & Type of finish \\
\hline 325002107181201 & $\mathrm{H} 4$ & 19940315 & Bored or augered & 8.6 & 2.0 & 20.3 & 9 & Bentonite & 10.3 & 19.7 & 9.3 & Gravel pack w/screen \\
\hline 324122107120802 & H13 & 20051115 & Bored or augered & 6.6 & 2.0 & 28.1 & 8 & Bentonite & 13.5 & 23.5 & 10.0 & Gravel pack w/screen \\
\hline 324021107114301 & H19 & 19940314 & Bored or augered & 8.6 & 2.0 & 17.0 & 6 & Bentonite & 7.0 & 16.4 & 9.3 & Gravel pack w/screen \\
\hline 323930107041401 & $\mathrm{H} 30$ & 19940318 & Bored or augered & 8.6 & 2.0 & 23.3 & 12 & Bentonite & 13.3 & 22.6 & 9.3 & Gravel pack w/screen \\
\hline 323917107031601 & $\mathrm{H} 29$ & 19940317 & Bored or augered & 8.6 & 2.0 & 18.2 & 7 & Bentonite & 8.2 & 17.5 & 9.3 & Gravel pack w/screen \\
\hline 323802107024101 & $\mathrm{H} 27$ & 19940319 & Bored or augered & 8.6 & 2.0 & 16.9 & 5 & Bentonite & 6.9 & 16.2 & 9.3 & Gravel pack w/screen \\
\hline 323722107002801 & $\mathrm{H} 25$ & 19940318 & Bored or augered & 8.6 & 2.0 & 23.0 & 12 & Bentonite & 13.1 & 22.4 & 9.3 & Gravel pack w/screen \\
\hline 322540106525101 & M43 & 20090121 & Bored or augered & 8.0 & 2.0 & 34.5 & 2 & Bentonite & 4.5 & 24.5 & 20.0 & Gravel pack w/screen \\
\hline 321859106503101 & M16 & 20090218 & Bored or augered & 8.0 & 2.0 & 34.0 & 2 & Bentonite & 4.0 & 24.0 & 20.0 & Gravel pack w/screen \\
\hline 321105106442101 & M8 & 20090220 & Bored or augered & 8.0 & 2.0 & 34.0 & 3 & Bentonite & 4.0 & 24.0 & 20.0 & Gravel pack w/screen \\
\hline 320404106385801 & M23 & 20090202 & Bored or augered & 8.0 & 2.0 & 33.5 & 3 & Bentonite & 3.5 & 23.5 & 20.0 & Gravel pack w/screen \\
\hline 315953106390601 & M39 & 20090122 & Bored or augered & 8.0 & 2.0 & 34.0 & 2 & Bentonite & 4.0 & 24.0 & 20.0 & Gravel pack w/screen \\
\hline 314816106325901 & ISC4 & 20090203 & Bored or augered & 8.0 & 2.0 & 34.2 & 3 & Bentonite & 4.2 & 24.2 & 20.0 & Gravel pack w/screen \\
\hline
\end{tabular}




\section{Seepage}

Data for seepage investigations in the Mesilla Valley (between RG-LB and RG-EP) were collected in February from 2009 to 2013, and once in July 2012. These data have been reported in detail in Crilley and others (2013) and Gunn and Roark (2014). For the current investigation, the main-stem Rio Grande seepage data were selected from these reports and mapped to better understand the spatial and temporal distribution of gaining and losing reaches in the Mesilla Valley. There were reaches that had no surface-water flow during these low-flow seepage investigations and therefore did not contribute to the cumulative seepage flux values (Crilley and others, 2013). Where surface-water flow occurs, the reaches are likely losing water to the groundwater system (Crilley and others, 2013).

\section{Temporal Variability of Surface-Water Discharge and Surface-Water Quality}

The temporal variability of surface-water discharge and surface-water quality was assessed at each of the streamgages in the study area with available data from 2009 to 2013. Annual and dynamic seasonal DS loads, based on release and nonrelease seasons, were calculated using daily surface-water discharge and DS concentration data converted from SC data at study area streamgages (fig. 3). A mass-balance approach between streamgages was used to calculate the change in DS load, or the mass of salt added to or removed between streamgages, in the Rincon and Mesilla Valleys.

The continuous daily-mean discharge and SC data (McKean and others, 2014) from RG-CB, RG-LB, and RG-EP were used for this study. Instantaneous discharge data (measured in cubic meters per second) were converted to daily values (cubic meters per day) to align the temporal resolution of surface-water discharge and SC data. Time series of these data show their inverse relation; when discharge is greatest, $\mathrm{SC}$ values are lowest, and when surface-water discharge is lowest, $\mathrm{SC}$ values are greatest (fig. 4).

\section{Release and Nonrelease Seasons}

Seasonal high flow is the result of release from Caballo Reservoir; therefore, the temporal variability of the release dates are not naturally or hydrologically defined but are caused by dam operations. The variable release dates are caused by management decisions and make static, calendardefined temporal definitions of release and nonrelease seasons inadequate to describe the system. Previous studies defined the irrigation season as March through September (Moore and others, 2008; Moyer and others, 2013) and calculated loads using this seasonal definition. The current study defines a release season that is separate from this static irrigation season. Although crop irrigation primarily occurs between March and September, surface water from the Rio Grande Project was not provided for the duration of the irrigation season during the study period because of limits on availability related to drought.

\section{Release and Nonrelease Volumetric Flow Definition}

A static seasonal definition of high flow does not capture the temporally-dynamic release timing and duration observed during the study period. During periods of no release (nonrelease), instantaneous discharge measured at RG-CB, RG-LB, and RG-EP is generally less than 10 cubic feet per second ( $\mathrm{ft}^{3} / \mathrm{s} ; 24,465 \mathrm{~m}^{3} / \mathrm{d}$ ) (McKean and others, 2014). Instantaneous discharge measured at these three streamgages downstream from Caballo Dam is generally substantially greater during periods of release than during nonrelease periods.

A volumetric definition of release season was defined using a threshold value of $500,000 \mathrm{~m}^{3} / \mathrm{d}$ at RG-CB (fig. 4), and this temporal definition for release season for each year was also applied to RG-LB and RG-EP to determine the number of days of above-threshold flow at each streamgage in the study area. Instantaneous discharge values were used to calculate daily flow. Periods of discharge greater than the threshold value were defined as release seasons, and periods of discharge less than the threshold value were defined as nonrelease seasons. The total number of release and nonrelease days per calendar year is similar at each streamgage and show a progressively shorter release season for the study period (table 2); shorter release seasons during the study period were caused by management decisions and legal obligations for the Rio Grande Project area related to drought.

Daily-calculated DS loads were aggregated over annual and dynamic seasonal periods for each calendar year in the study period. The dynamic release and nonrelease seasons (as defined by the release season threshold value of $500,000 \mathrm{~m}^{3} / \mathrm{d}$ ) were used to assess the temporal variability of water quality in the study area. Depth to groundwater, SC, and calculated DS load data were grouped by calendar year to compare to calendar-year variables, and data were then further grouped within the calendar year into release and nonrelease seasons. To compare overall release to nonrelease season data, all daily data for the study period were grouped into release and nonrelease seasons. To compare season-to-season response to timing and duration of the release season, each release season was defined as a different group, with nonrelease seasons spanning the winter months and crossing into the next calendar year. 


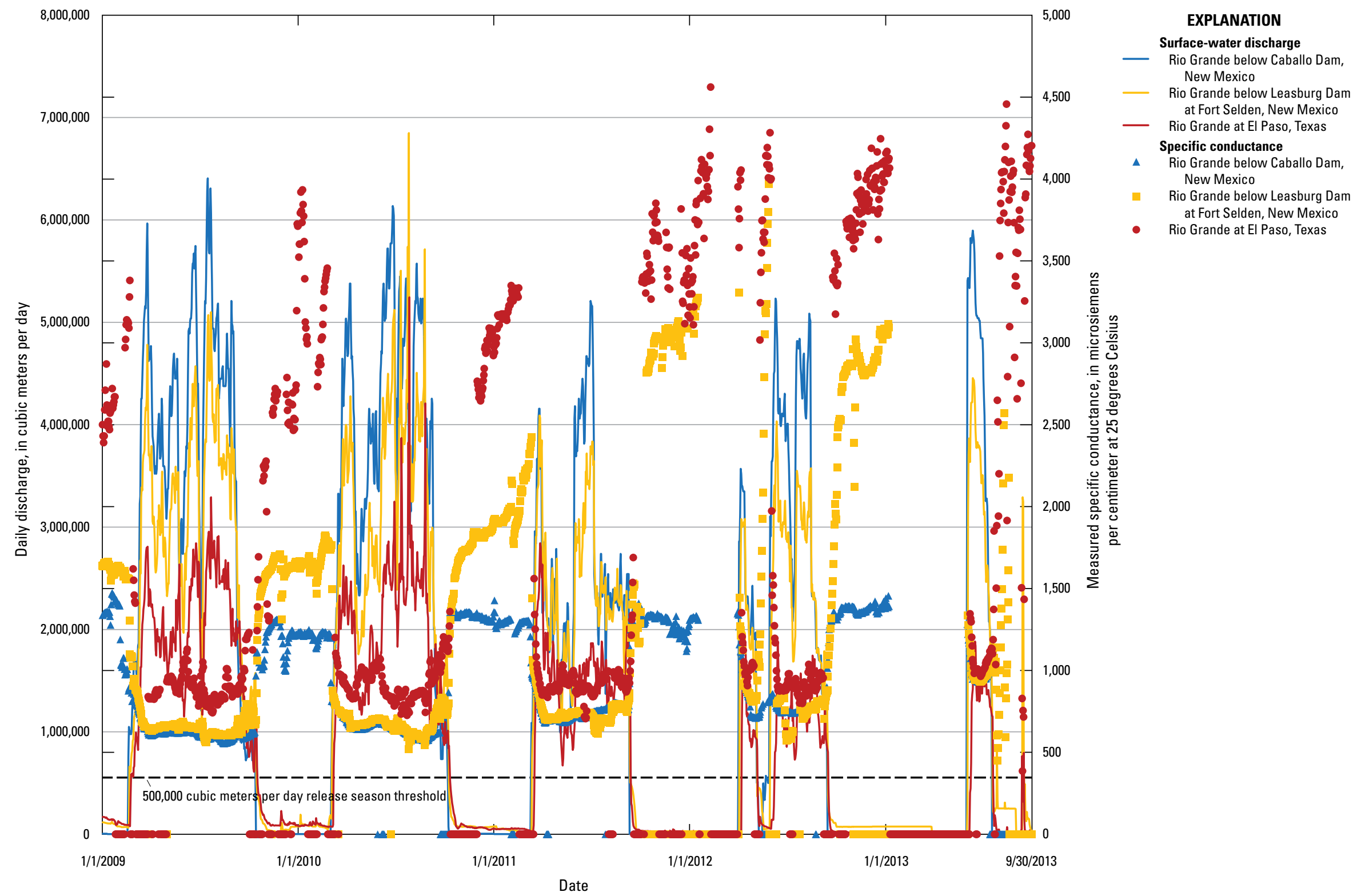

Figure 4. Daily surface-water discharge and specific conductance at three Rio Grande streamgages: Rio Grande below Caballo Dam; Rio Grande below Leasburg Dam; and Rio Grande at El Paso from January 1, 2009, to September 30, 2013. 
Table 2. Number of days of discharge greater than the release season threshold value $(500,000$ cubic meters per day at the streamgage below Caballo Dam) at each streamgage, 2009-13.

[USGS, U.S. Geological Survey; ID, identifier]

\begin{tabular}{lccccc}
\hline \multicolumn{1}{c}{ Streamgage } & $\mathbf{2 0 0 9}$ & $\mathbf{2 0 1 0}$ & $\mathbf{2 0 1 1}$ & $\mathbf{2 0 1 2}$ & $\mathbf{2 0 1 3}$ \\
\hline Rio Grande below Caballo Dam, New Mexico (USGS ID: 08362500) & 238 & 217 & 184 & 151 & 43 \\
$\begin{array}{l}\text { Rio Grande below Leasburg Dam at Fort Selden, New Mexico (USGS } \\
\text { ID: 08363510) }\end{array}$ & 238 & 218 & 184 & 141 & 47 \\
Rio Grande at El Paso, Texas (USGS ID: 08364000) & 236 & 218 & 180 & 131 & 44 \\
\hline
\end{tabular}

\section{Temporal Variability of Dissolved- Solids Loads}

Salt loads, or the mass of salt per unit time, in the Rio Grande at each streamgage in the study area quantify the amount of salt entering and leaving the study area valleys through surface water. Calculation of salt loads (mass per unit time) instead of concentration provides information about processes other than evapoconcentration that influence the addition or subtraction of salt mass to the system. Deep groundwater with high DS may be a source (the addition of salt mass) to the surface water through both groundwater upwelling and deep groundwater pumping. The lowering of groundwater levels may be a sink (subtraction of salt mass), resulting in flux from surface water to groundwater in the study area.

Salt sinks in the valleys include salts left behind in soils after irrigation water evaporates at the end of the growing season. These accumulated salts could potentially be flushed out of the valley in a subsequent precipitation or irrigation event. A salt sink (more salt staying in the valley than leaving) may represent the recycling of salt through conjunctive use because the same water used for multiple irrigation cycles would result in iterative evapoconcentration of salt, keeping the salt mass within the valley. Salt sources in the valleys include (1) flushing of previously left-behind salts from the unsaturated zone during irrigation and subsequent transport to streams, and (2) the natural upwelling of salty groundwater and (or) pumping of deep groundwater with high DS, which is applied to fields and returns to the surface water through agricultural drains. A salt source (more salt leaving than entering the valley) may represent a previously unaccounted for source of salt (such as deep groundwater) contributing to the surface water (drains or Rio Grande flow) and influencing surface-water quality. Increased groundwater withdrawal for irrigation may be recirculating previously evapoconcentrated waters, keeping salt in the basin. Accumulation of salt in the basin can have a negative effect on agricultural practices.

\section{Daily and Seasonal Dissolved-Solids Loads}

Daily DS loads in the Rio Grande were calculated for each streamgage (RG-CB, RG-LB, RG-EP), which required the same time interval for each data parameter. Gaps in the SC data were filled using linear interpolation between measured values (previously described in the "Approach Surface Water" section). These data gaps were larger downstream from RGEP but usually coincided with minimal or no flow. Daily mean discharge in cubic meters per second $\left(\mathrm{V}_{\mathrm{d}}\right)$ was converted to cubic meters per day and multiplied by the daily DS value $\left(\mathrm{DS}_{\mathrm{d}}\right.$ ) in milligrams per liter after conversion from SC (eq. 1) and by unit conversion factor to calculate the daily load, in tons.

$$
\text { Daily Load }=\text { Load }_{d}=D S_{d} \times V_{d} \times \text { Conversion Factor }
$$

Daily loads were then aggregated to total annual loads based on the calendar year:

$$
\text { Annual Load }=\operatorname{Load}_{a}=\sum_{d=1}^{d=d a y m a x} \operatorname{Load}_{d}
$$

Loads at the three streamgages were also aggregated seasonally within each calendar year of the study period by summing each daily load value within the release or nonrelease season (fig. 5). For example, the aggregated nonrelease load for 2009 includes all nonrelease days falling within the 2009 calendar year, whether those nonrelease days fell prior to or subsequent to the 2009 release season.

Results show that the majority of the DS load occurs during the release season relative to the nonrelease season at each streamgage (fig. 5). For each year, the magnitude of the salt load decreases downstream. Annual loads generally decreased from 2009 to 2013 at each of the three gaging stations (fig. 5). 

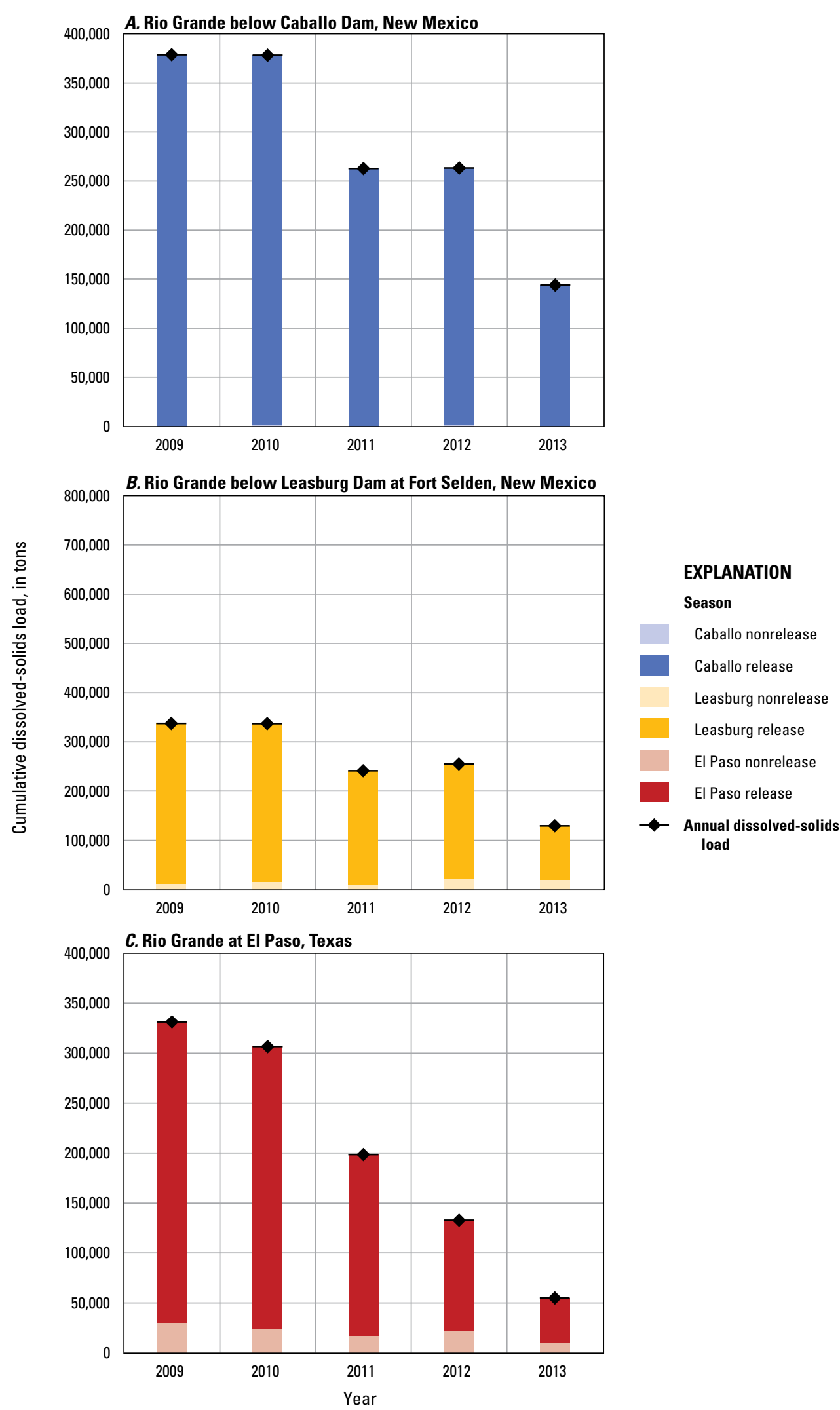

Figure 5. Seasonal and annual dissolved-solids loads from 2009 to 2013 in the Rio Grande Project area: $A$, Rio Grande below Caballo Dam; $B$, Rio Grande below Leasburg; and $C$, Rio Grande at El Paso. 


\section{Valley-Scale Mass-Balance Dissolved-Solids Loads}

The upstream and downstream bounds of the Rincon and Mesilla Valleys are approximately located at streamgage pairs in the study area (RG-CB to RG-LB and RG-LB to RG-EP, respectively) (Witcher and others, 2004). Valley-scale mass-balance DS loads were calculated by subtracting the downstream DS load (Salt Load ${ }_{\text {out }}$ ) from the upstream DS load $\left(\right.$ Salt Load $_{\text {in }}$ ) for both the Rincon and Mesilla Valleys over annual and seasonal timescales:

$$
\Delta \text { Salt Load }={\text { Salt } \text { Load }_{\text {in }}-\text { Salt Load }}_{\text {out }}
$$

When the mass of salt in the Rio Grande at the entrance to a valley $\left(\right.$ Salt Load $\left._{i n}\right)$ is equal to the amount of salt in the Rio Grande at the exit from the valley (Salt Load $_{\text {out }}$ ), the change in load ( $\triangle$ Salt Load) equals zero. However, if salt is added to the surface-water system from another source (such as the flushing of prior salt accumulation in soils or the inflow of salt from geologic sources through deep groundwater flow paths) or removed from the surface-water system (such as through salt accumulation in soils after irrigation), the change in load will be a positive or negative value, respectively. When $\Delta$ Salt Load is positive, there is more salt entering the valley than leaving (the valley acts as a sink of salt); when $\Delta$ Salt Load is negative, there is more salt leaving the valley than entering (the valley acts as a source of salt).

Daily $\Delta$ Salt Load values were aggregated to calculate the cumulative $\Delta$ Salt Load at various timescales to capture the temporal dynamics of the system. The daily $\Delta$ Salt Load values were aggregated for each year to give cumulative annual totals and normalized for the days of year measured to include 2013, which does not have a full calendar year of data. These day-normalized annual loads show no consistent increasing or decreasing trend from 2009 to 2013 in the Rincon Valley and an increasing trend in the Mesilla Valley from 2009 to 2012 (2013 is not a full year of data) (fig. 6A,B). Cumulative $\Delta$ Salt Load values were also calculated seasonally (release and nonrelease). Both valleys show negative $\Delta$ Salt Load during the nonrelease season (from 2009 to 2013 in the Rincon Valley and from 2009 to 2011 in the Mesilla Valley) (fig. 6A, B). Over the study period, nonrelease $\Delta$ Salt Load values generally become more negative during the nonrelease season in the Rincon and less negative in the Mesilla, where the values were positive in 2012 and 2013. The $\Delta$ Salt Load values for release seasons are positive for both the Rincon and Mesilla Valleys, though there is a generally decreasing trend over the study period in the Rincon Valley and a generally increasing trend in the Mesilla Valley. The 2013 seasonal data include the full release season but only a partial nonrelease season. While both valleys had a positive annual salt balance (more salt entering than leaving), opposing trends in $\Delta$ Salt Load magnitude in the Rincon and Mesilla Valleys over the study period show relatively more salt leaving the Rincon Valley over time and more salt remaining in the Mesilla Valley over time. These differences could be caused by differences in the conjunctive use of water or the natural connectivity to deep groundwater between the two valleys.

\section{Spatiotemporal Variability of Shallow Groundwater Level and Quality}

Daily time series of depth to groundwater and SC data, measured by in-situ probes in shallow wells in the Rincon and Mesilla Valleys, were compared to daily streamgage discharge and SC data by grouping data in the same release/nonrelease seasons defined by surface-water discharge volume (fig. 7). Daily data from each well were temporally aggregated using three methods for analysis: (1) all data grouped into release and nonrelease seasons over the study period (groups: release and nonrelease); (2) all data first grouped by calendar year and then by nonrelease seasons, for example: data for all nonrelease days falling within the 2009 calendar year, whether those nonrelease days fell prior to or subsequent to the 2009 release season (groups: 2009 release, 2009 nonrelease, 2010 release, 2010 nonrelease, 2011 release, 2011 nonrelease, 2012 release, 2012 nonrelease); (3) all data grouped by release and nonrelease seasons, independent of calendar year, for example: data following the 2009 release season would be categorized as nonrelease until the start of the 2010 release season (groups: pre-2009 release season, 2009 release season, pre-2010 release season, 2010 release season, pre-2011 release season, 2011 release season, pre-2012 release season, 2012 release season). Each of these data grouping methods were used in different ways to summarize the variability of shallow groundwater data over the study period.

The seasonal variability of shallow groundwater SC values (and therefore DS concentrations because of the linear relation of these variables, fig. 2) may show the influence of water recently used for irrigation on groundwater quality. Surface water applied for irrigation likely infiltrates to recharge shallow groundwater and agricultural soils in flood irrigated fields, which may hold salts from previous growing seasons after the evapoconcentration of irrigation waters. While shallow groundwater SC and depth to groundwater do appear to respond within days of the start of surface-water release, there is likely a temporal lag between surface-water discharge conditions and shallow groundwater response because of the time required to route water to the fields, and the time to infiltrate to the water table. 

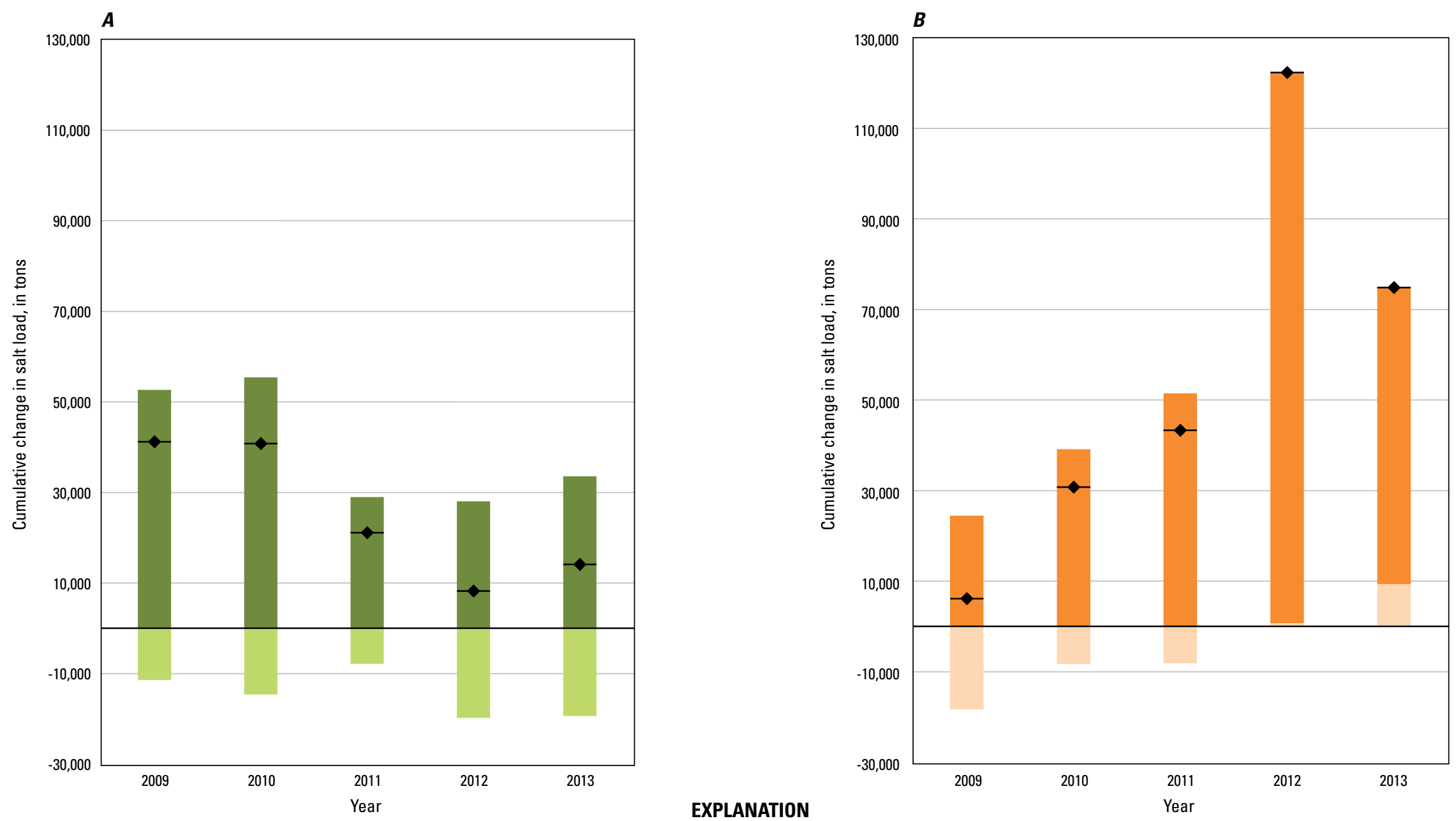

\section{EXPLANATION}

Season

Rincon Valley nonrelease

Rincon Valley release

Mesilla Valley nonrelease

Mesilla Valley release

$\checkmark$ Annual change in salt load

Figure 6. Cumulative $\Delta$ Salt Load changes by nonrelease and release seasons within calendar years for $A$, the Rincon Valley, and $B$, the Mesilla Valley in the Rio Grande Project area, January 1, 2009, through September 30, 2013. 


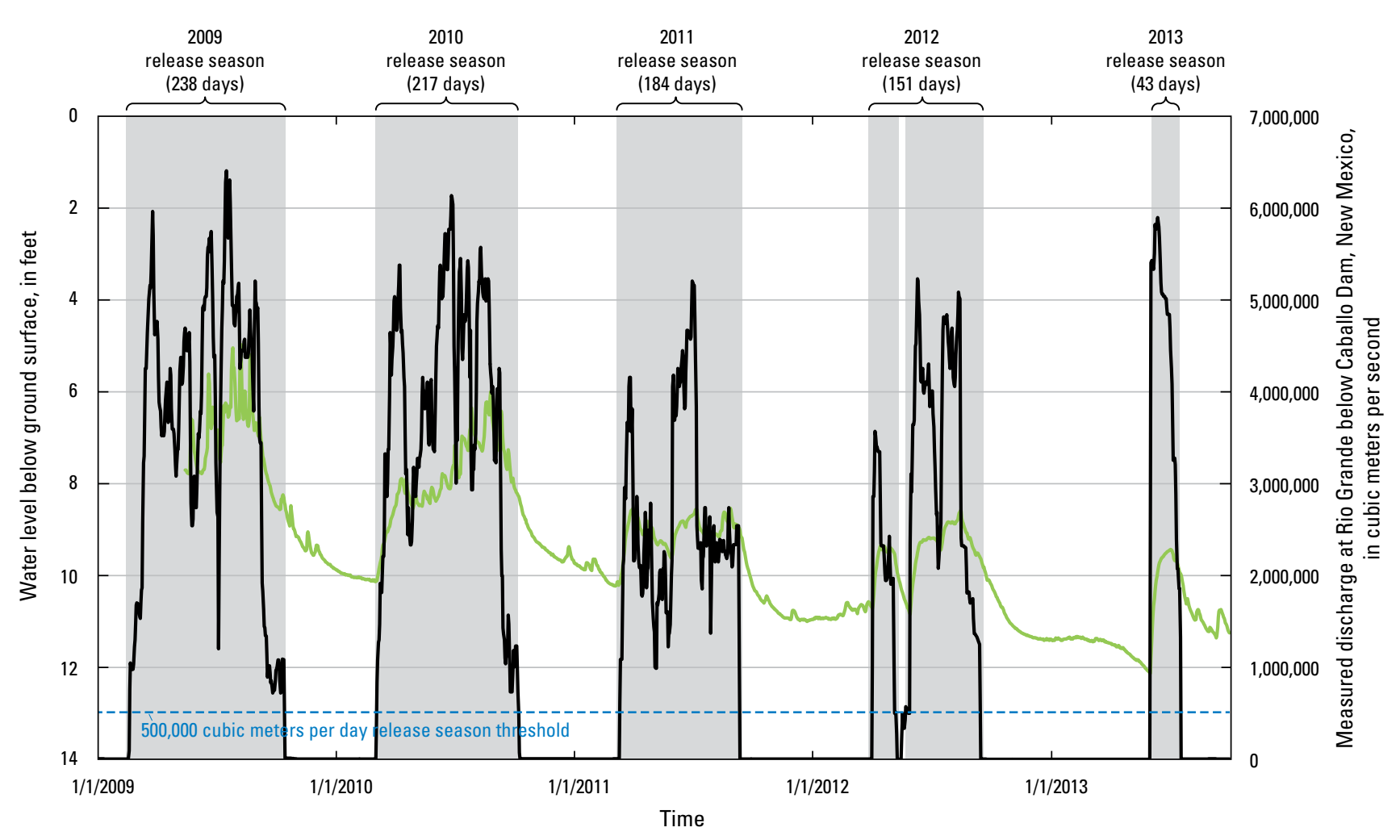

EXPLANATION

Approximate release season

Daily depth to groundwater in an example well (H27)

Daily measured discharge (Rio Grande below Caballo Dam, New Mexico)

Figure 7. Example of seasonal and annual grouping of groundwater data using surface-water discharge-defined release/nonrelease seasons in the Rio Grande Project area.

\section{Annual Shallow Groundwater Trends}

Daily groundwater-level and SC data for individual wells were used to calculate annual and seasonal mean values (tables 3 and 4). Available data for shallow wells during the study period (2009-13) show a consistent increase in annual mean depth to groundwater values (water-level decline) in both Rincon and Mesilla Valleys. Shallow groundwater SC values, however, exhibit wide variability. Disconnection of temporal variability between groundwater-level and SC values illustrates the heterogeneity of the shallow groundwater system at these well locations, possibly indicating different sources influencing water quality in the study area.

\section{Seasonal Shallow Groundwater Response}

Changes between seasonal mean depth to groundwater and mean SC values (delta values, tables 3 and 4) were calculated for each year for each well in the Rincon and Mesilla Valleys. These changes, or delta values, were calculated to measure the degree of seasonal response to surface-water releases. A seasonal response may indicate influence from irrigation practices on shallow groundwater. For groundwater SC delta values, positive delta values indicate an increase in the $\mathrm{SC}$ of groundwater from nonrelease to release season, whereas negative delta values indicate a decrease in the $\mathrm{SC}$ of groundwater from nonrelease to release season. For depth to groundwater, positive delta values indicate a water table decrease from nonrelease to release season, and negative values indicate a water table increase from nonrelease to release season. For SC and depth to groundwater, the standard deviation of the delta value for each individual well over the study period was calculated. The standard deviation (Helsel and Hirsch, 2002) of these values within each Valley shows the relative variability of $\mathrm{SC}$ and depth to groundwater. For SC, the average of the standard deviation of the individual wells in the Rincon Valley $(184.73 \mu \mathrm{S} / \mathrm{cm})$ shows less variability relative to the Mesilla Valley $(441.37 \mu \mathrm{S} / \mathrm{cm})$. For depth to groundwater, the average of the standard deviation of the individual wells in the Rincon Valley $(1.15 \mathrm{ft})$ shows greater variability relative to the Mesilla Valley $(0.62 \mathrm{ft})$. 
Table 3. Annual mean and seasonal mean depth to groundwater and specific-conductance data from wells in the Rincon Valley in the Rio Grande Project area, New Mexico and Texas, 2009-13.

[ID, identifier; release is the Caballo streamgage-defined release season; nonrelease is the Caballo streamgage-defined nonrelease season within the calendar year; NA indicates no data are available; delta is the nonrelease mean value minus the release mean value]

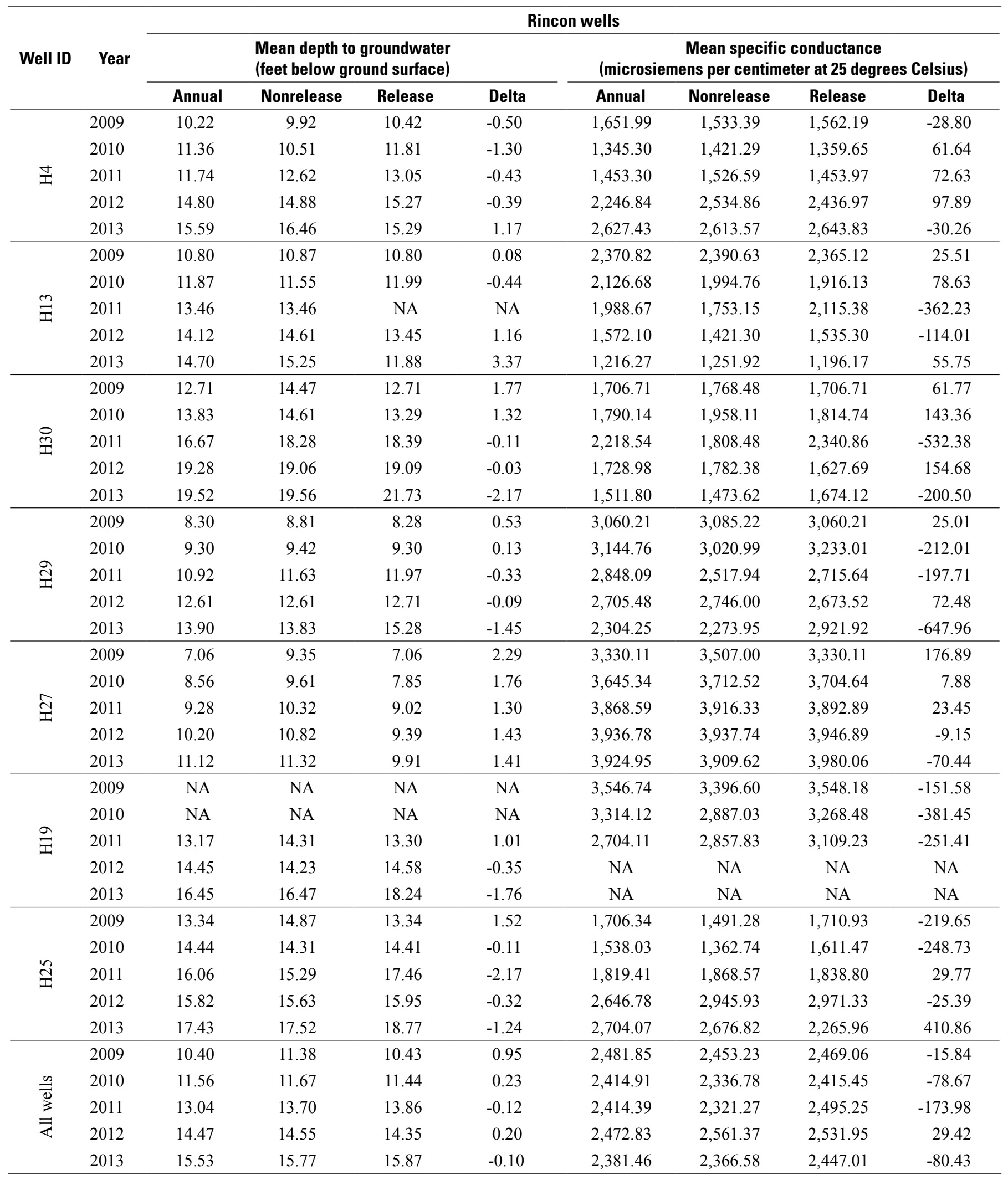


Table 4. Annual mean and seasonal mean depth to groundwater and specific-conductance data from wells in the Mesilla Valley in the Rio Grande Project area, New Mexico and Texas, 2009-13.

[ID, identifier; release is the Caballo streamgage-defined release season; nonrelease is the Caballo streamgage-defined nonrelease season within the calendar year; NA indicates no data are available; delta is the nonrelease mean value minus the release mean value]

\begin{tabular}{|c|c|c|c|c|c|c|c|c|c|}
\hline \multirow{3}{*}{ Well ID } & \multirow{3}{*}{ Year } & \multicolumn{8}{|c|}{ Mesilla wells } \\
\hline & & \multicolumn{4}{|c|}{$\begin{array}{l}\text { Mean depth to groundwater } \\
\text { (feet below ground surface) }\end{array}$} & \multicolumn{4}{|c|}{$\begin{array}{l}\text { Mean specific conductance } \\
\text { (microsiemens per centimeter at } 25 \text { degrees Celsius) }\end{array}$} \\
\hline & & Annual & Nonrelease & Release & Delta & Annual & Nonrelease & Release & Delta \\
\hline \multirow{5}{*}{$\stackrel{\tilde{P}}{\Sigma}$} & 2009 & 9.77 & 11.03 & 9.77 & 1.26 & $2,916.81$ & $3,370.08$ & $2,916.81$ & 453.26 \\
\hline & 2010 & 10.17 & 11.17 & 9.56 & 1.62 & $3,184.34$ & $3,113.86$ & $3,187.46$ & -73.60 \\
\hline & 2011 & 10.71 & 12.08 & 10.25 & 1.83 & $3,189.99$ & $3,173.74$ & $3,166.51$ & 7.22 \\
\hline & 2012 & 11.83 & 12.53 & 10.70 & 1.83 & $2,659.59$ & $2,499.81$ & $2,361.90$ & 137.91 \\
\hline & 2013 & 12.68 & 13.08 & 10.78 & 2.30 & $1,775.37$ & $1,726.55$ & $1,731.68$ & -5.13 \\
\hline \multirow{5}{*}{$\stackrel{b}{\Sigma}$} & 2009 & 9.08 & 9.85 & 9.08 & 0.77 & $1,711.51$ & $1,703.56$ & $1,711.51$ & -7.95 \\
\hline & 2010 & 9.93 & 11.10 & 9.95 & 1.14 & $1,891.89$ & $2,248.61$ & $1,929.09$ & 319.53 \\
\hline & 2011 & 12.56 & 13.67 & 13.68 & -0.01 & $2,219.40$ & $2,263.37$ & $2,149.78$ & 113.59 \\
\hline & 2012 & 15.92 & 15.63 & 16.93 & -1.31 & $2,318.49$ & $2,467.82$ & $2,262.28$ & 205.54 \\
\hline & 2013 & 17.53 & 17.51 & 19.43 & -1.91 & $2,445.35$ & $2,469.54$ & 2,223.64 & 245.90 \\
\hline \multirow{5}{*}{$\sum^{\infty}$} & 2009 & 8.99 & 9.33 & 8.99 & 0.34 & $2,373.90$ & $2,403.39$ & $2,373.90$ & 29.49 \\
\hline & 2010 & 9.18 & 9.41 & 9.03 & 0.38 & $2,386.83$ & $2,395.15$ & $2,384.76$ & 10.39 \\
\hline & 2011 & 9.17 & 9.36 & 8.96 & 0.40 & $2,540.95$ & $2,603.19$ & $2,605.75$ & -2.56 \\
\hline & 2012 & 9.41 & 9.59 & 9.31 & 0.28 & $2,835.38$ & $2,906.90$ & $2,925.85$ & -18.95 \\
\hline & 2013 & 9.52 & 9.55 & 9.41 & 0.14 & $3,067.10$ & $3,081.03$ & $3,063.55$ & 17.47 \\
\hline \multirow{5}{*}{$\stackrel{\tilde{\Sigma}}{\Sigma}$} & 2009 & 9.51 & 10.32 & 9.51 & 0.81 & $2,779.94$ & $2,905.56$ & $2,779.94$ & 125.62 \\
\hline & 2010 & 10.36 & 10.43 & 10.30 & 0.13 & $2,805.77$ & $2,514.61$ & $2,806.64$ & -292.03 \\
\hline & 2011 & 11.94 & 13.24 & 13.15 & 0.09 & $2,556.28$ & $3,064.17$ & $2,644.14$ & 420.03 \\
\hline & 2012 & 14.42 & 14.00 & 14.58 & -0.58 & $3,635.74$ & $3,933.18$ & $3,663.54$ & 269.64 \\
\hline & 2013 & 14.78 & 14.82 & 15.66 & -0.84 & $4,309.23$ & $4,284.66$ & $4,240.09$ & 44.57 \\
\hline \multirow{5}{*}{ 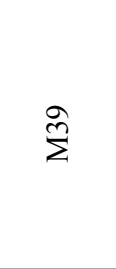 } & 2009 & 9.08 & 10.54 & 9.08 & 1.47 & 848.29 & $2,666.86$ & $2,779.94$ & -113.08 \\
\hline & 2010 & 10.81 & 11.39 & 10.72 & 0.66 & $1,581.53$ & $1,257.33$ & $2,806.64$ & $-1,549.30$ \\
\hline & 2011 & 12.60 & 13.93 & 13.44 & 0.49 & $1,043.40$ & $1,240.93$ & $2,644.14$ & $-1,403.21$ \\
\hline & 2012 & 15.60 & 15.63 & 15.95 & -0.32 & $1,464.73$ & $1,356.64$ & $3,663.54$ & $-2,306.90$ \\
\hline & 2013 & 17.43 & 17.52 & 18.77 & -1.24 & $1,509.70$ & $1,537.84$ & $4,240.09$ & $-2,702.25$ \\
\hline \multirow{5}{*}{$\underset{\mathscr{Z}}{\mathbb{Z}}$} & 2009 & 5.10 & 5.81 & 5.10 & 0.71 & NA & NA & $11,365.74$ & NA \\
\hline & 2010 & 5.22 & 5.81 & 4.84 & 0.97 & $11,048.09$ & $11,013.68$ & $11,006.20$ & 7.48 \\
\hline & 2011 & 5.55 & 5.96 & 5.24 & 0.73 & $10,517.81$ & $10,338.49$ & $12,336.31$ & $-1,997.81$ \\
\hline & 2012 & 5.87 & 6.10 & 5.61 & 0.49 & $10,813.41$ & $9,924.09$ & $9,777.63$ & 146.46 \\
\hline & 2013 & 6.04 & 6.07 & 5.74 & 0.33 & $9,423.44$ & $9,394.17$ & $9,377.17$ & 17.00 \\
\hline \multirow{5}{*}{$\begin{array}{l}\frac{\infty}{\overline{0}} \\
\stackrel{3}{\bar{z}}\end{array}$} & 2009 & 8.59 & 9.48 & 8.59 & 0.89 & $2,126.09$ & $2,609.89$ & $3,987.97$ & 97.47 \\
\hline & 2010 & 9.28 & 9.88 & 9.07 & 0.82 & $3,816.41$ & $3,757.21$ & $4,020.13$ & -262.92 \\
\hline & 2011 & 10.42 & 11.37 & 10.79 & 0.59 & $3,677.97$ & $3,780.65$ & $4,257.77$ & -477.12 \\
\hline & 2012 & 12.18 & 12.25 & 12.18 & 0.06 & $3,954.55$ & $3,848.07$ & $4,109.12$ & -261.05 \\
\hline & 2013 & 13.00 & 13.09 & 13.30 & -0.20 & $3,755.03$ & $3,748.96$ & $4,146.04$ & -397.07 \\
\hline
\end{tabular}




\section{Variability of Surface-Water Quantity and Quality and Shallow Groundwater Levels and Quality}

Seasonally grouped depth to groundwater and SC data (independent of calendar year) were explored using boxplots over the study period (fig. 8). Boxplots are used to visually explore the distribution of data, in this case, the distribution of seasonally grouped shallow groundwater data. Boxplots for each well were qualitatively divided into three response categories:

1. study period response, which shows a same-direction trend for the entire study period (for example, depth to groundwater at well M16);

2. seasonal response, which shows greater seasonal variability (for example, depth to groundwater at well M43), while also exhibiting a trend over the entire study period; and

3. not clearly a part of response category (1) or (2).

The qualitative categorical analysis results show a different distribution for depth to groundwater and SC data.
Six shallow groundwater wells (H4, H29, H30, M16, M23, and M39) fall into the study period response category (1) for depth to groundwater. Four shallow groundwater wells (H27, M8, M43, and ISC4) fall into the seasonal response category (2) for depth to groundwater. Two shallow groundwater wells (H13 and H25) fall into response category (3) for depth to groundwater. There are more wells that show a seasonal response in the Mesilla Valley (three) relative to the Rincon Valley (one), and more wells overall in both valleys that show no seasonal response (six) relative to seasonal response (four).

Two shallow groundwater wells (M8 and H13) fall into the study period response category (1) for SC values. One shallow groundwater well (M16) falls into the seasonal response category (2) for SC values. Ten shallow groundwater wells (H4, H19, H30, H29, H27, H25, M43, M23, M39, and ISC4) fall into response category (3) for SC values. The lack of overall or release season response of SC may indicate the influence of other source waters on shallow groundwater water-quality trends in the Rincon and Mesilla Valleys. 

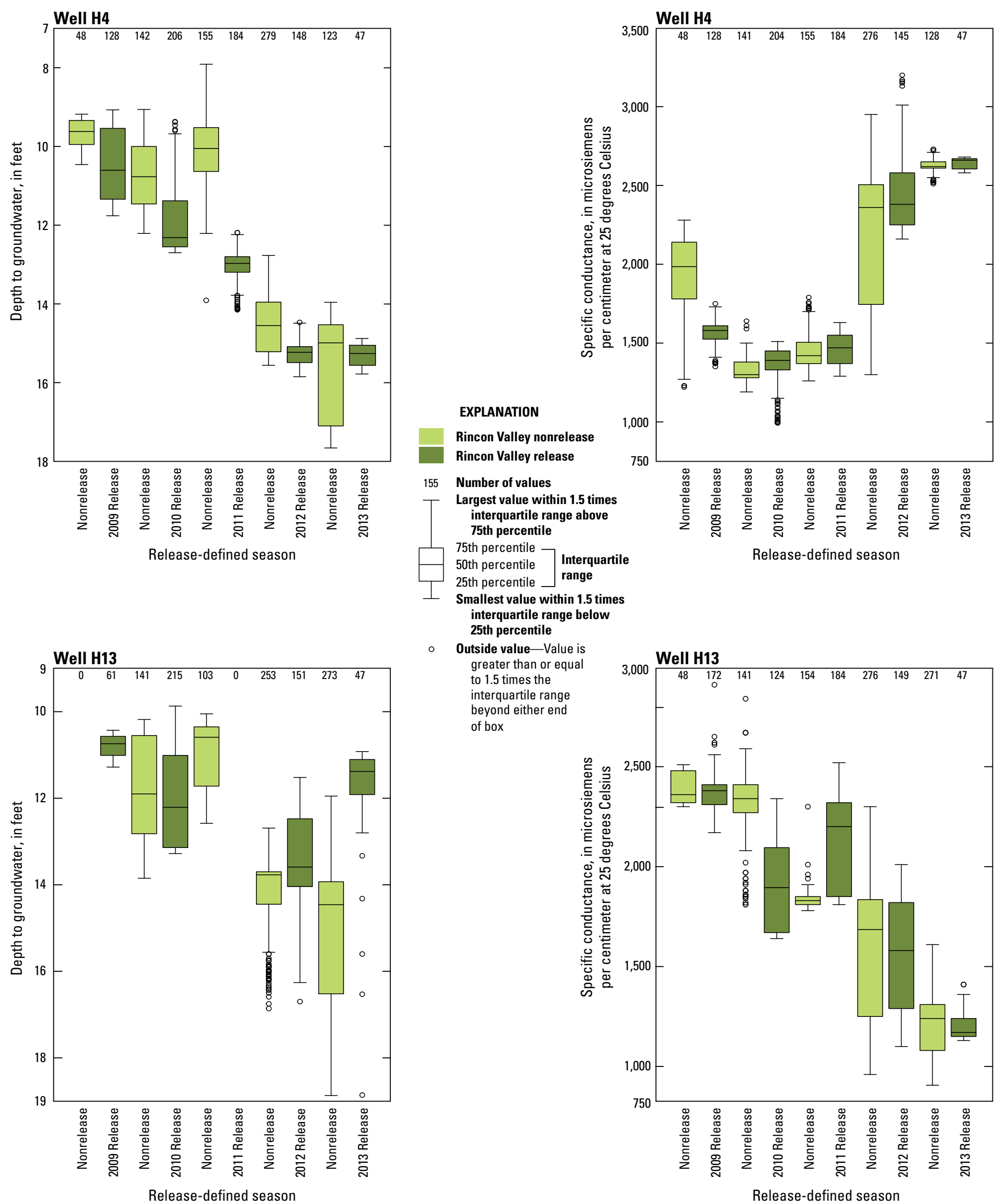

Figure 8. Seasonally grouped data showing overall and seasonal trends for depth to groundwater and specific conductance data for each shallow well in the Rio Grande Project area, New Mexico and Texas. 

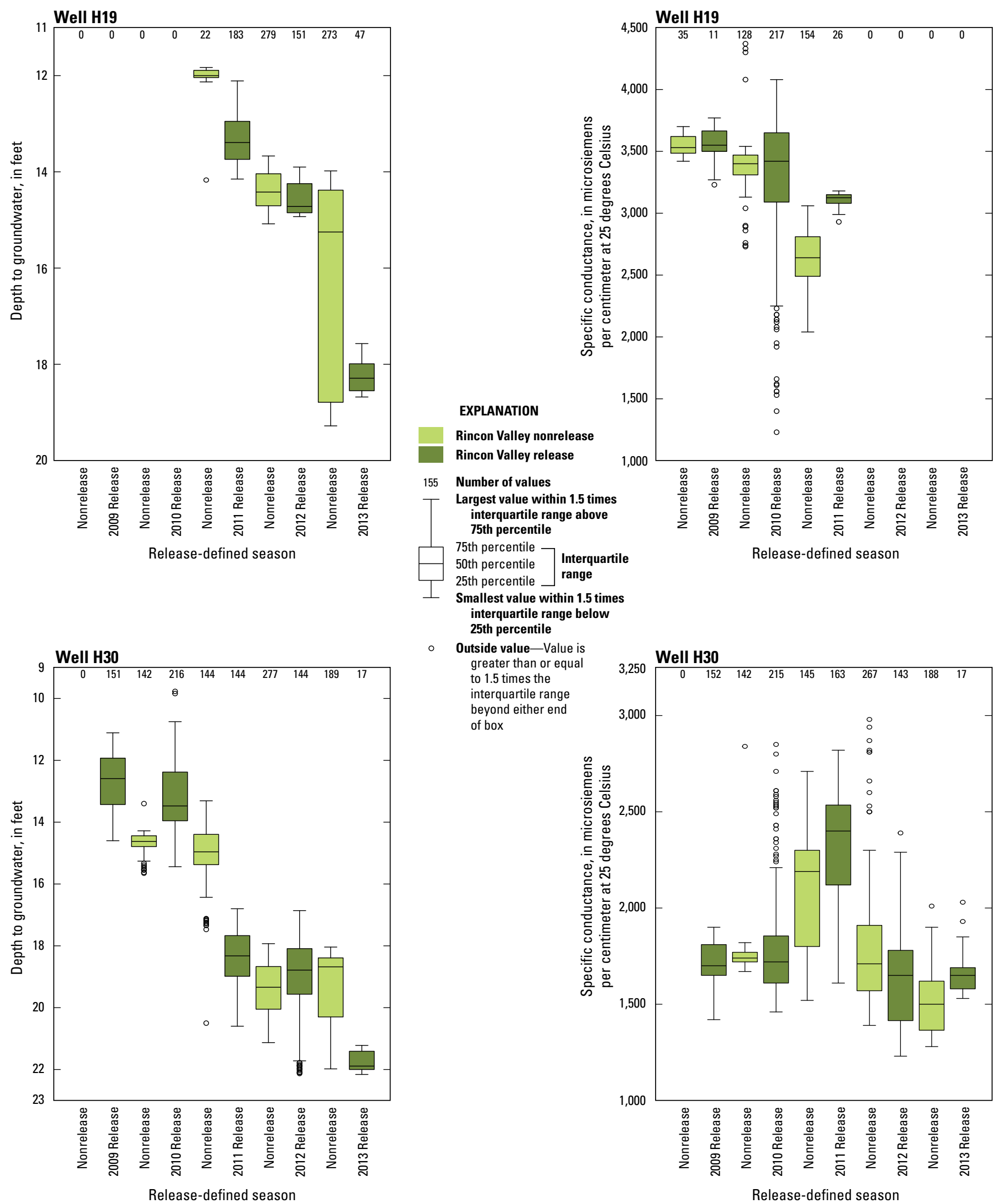

- Outside value-Value is greater than or equal to 1.5 times the interquartile range beyond either end of box

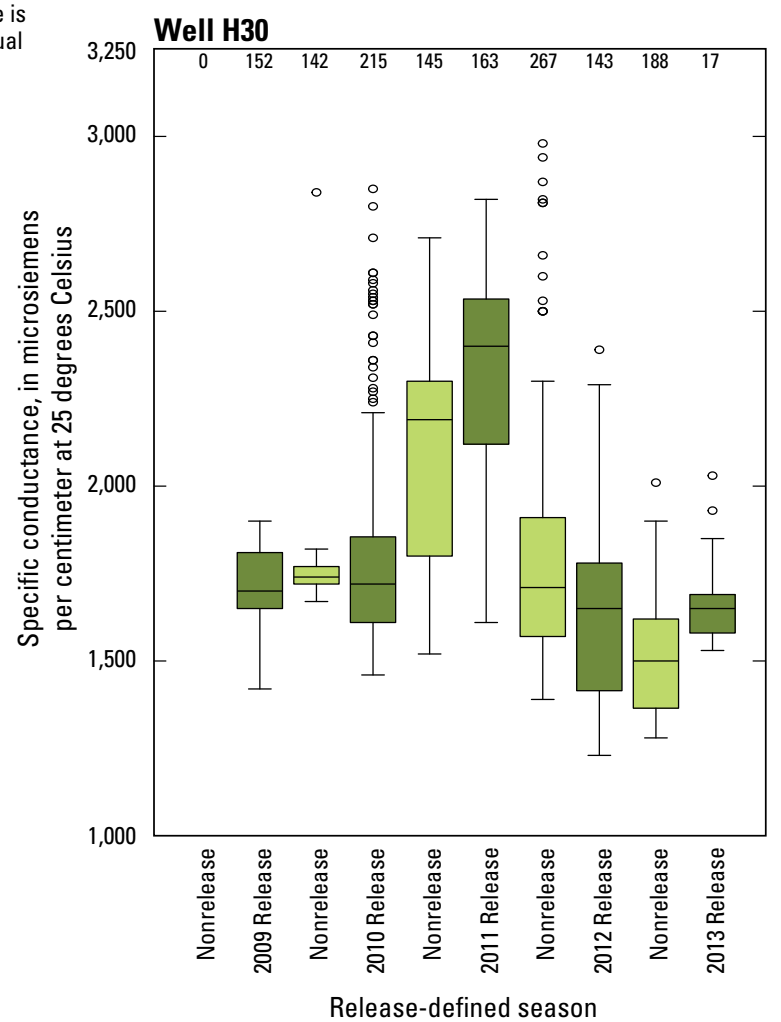

Figure 8. Seasonally grouped data showing overall and seasonal trends for depth to groundwater and specific conductance data for each shallow well in the Rio Grande Project area, New Mexico and Texas.-Continued 

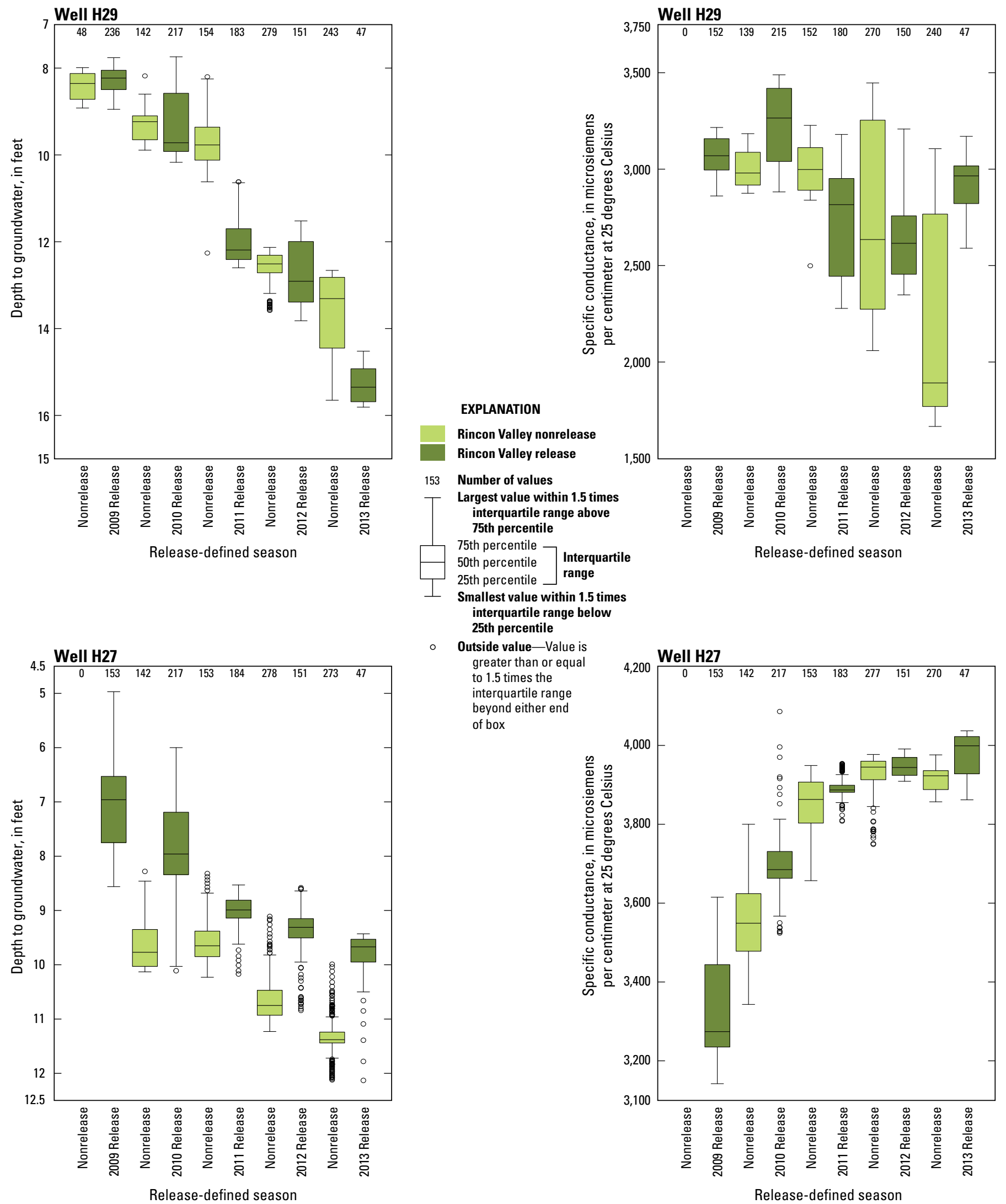

Release-defined season

Figure 8. Seasonally grouped data showing overall and seasonal trends for depth to groundwater and specific conductance data for each shallow well in the Rio Grande Project area, New Mexico and Texas.-Continued 

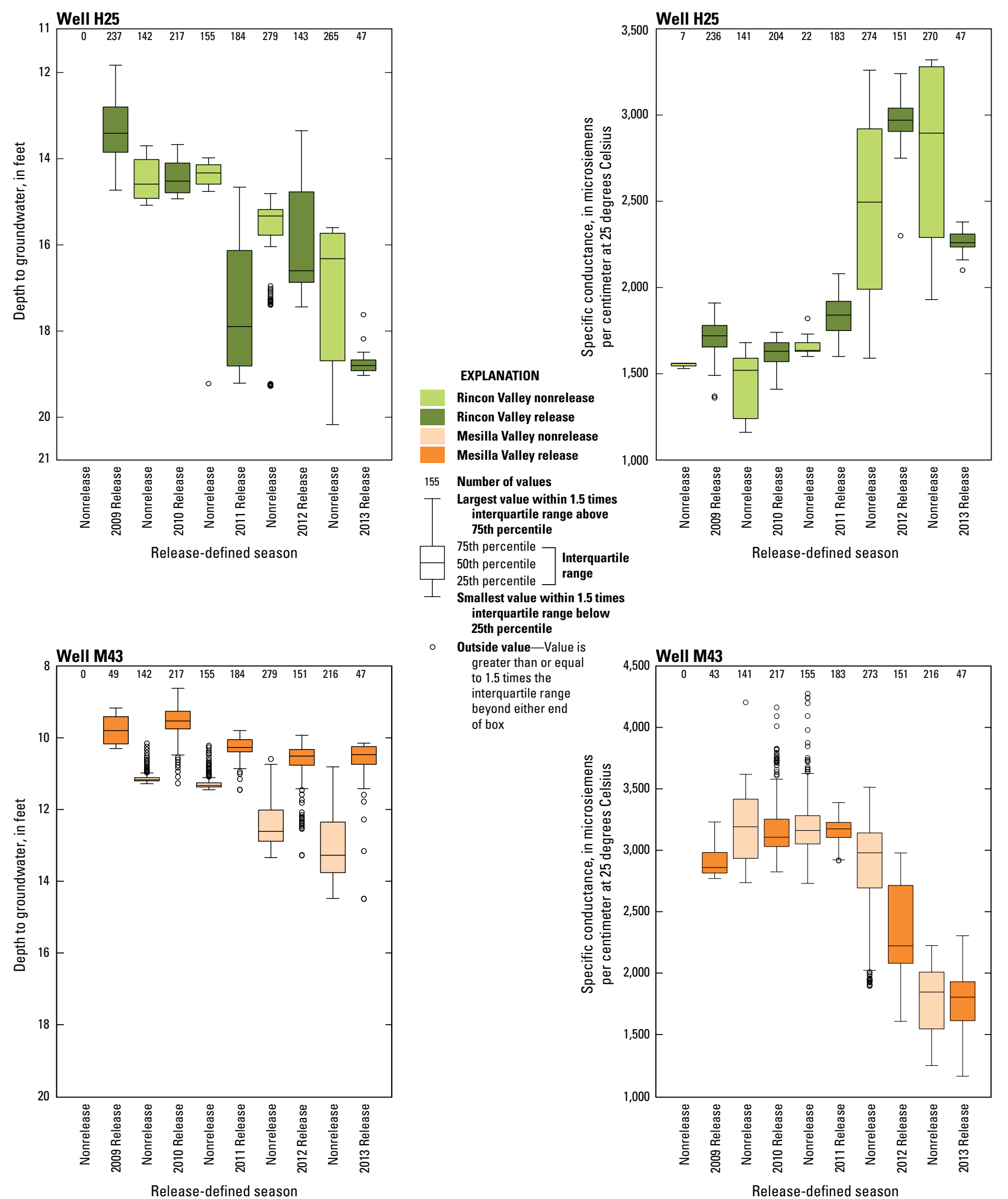

interquartile range below

25th percentile

- Outside value-Value is greater than or equal to 1.5 times the interquartile range beyond either end of box

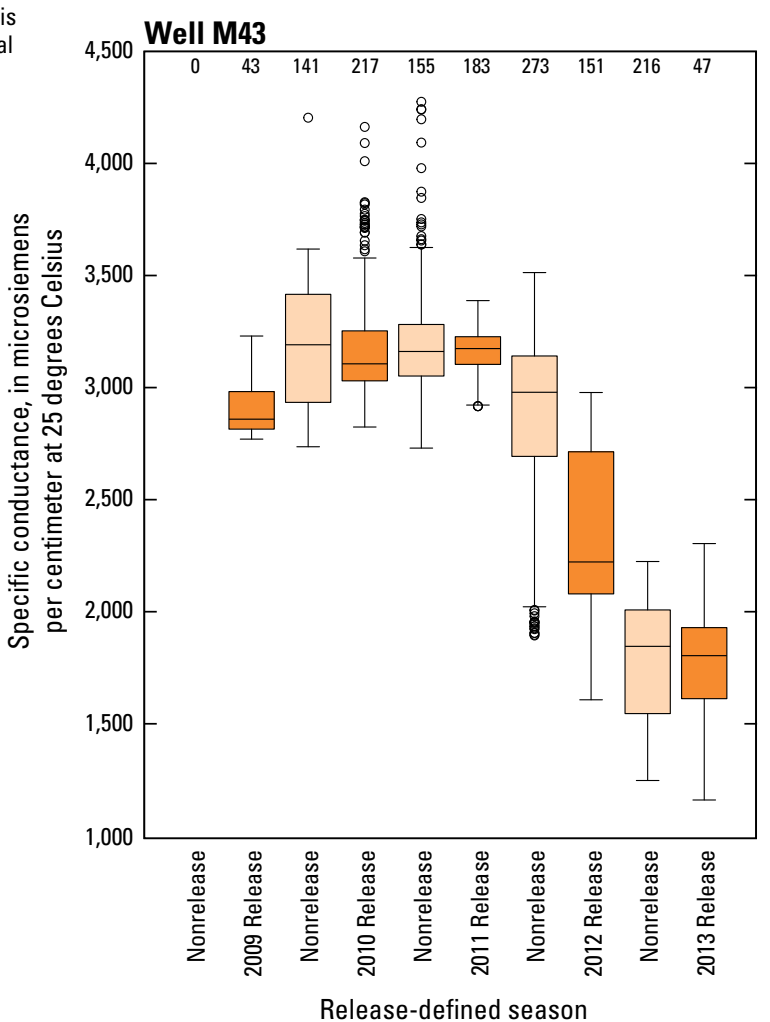

Figure 8. Seasonally grouped data showing overall and seasonal trends for depth to groundwater and specific conductance data for each shallow well in the Rio Grande Project area, New Mexico and Texas.-Continued 

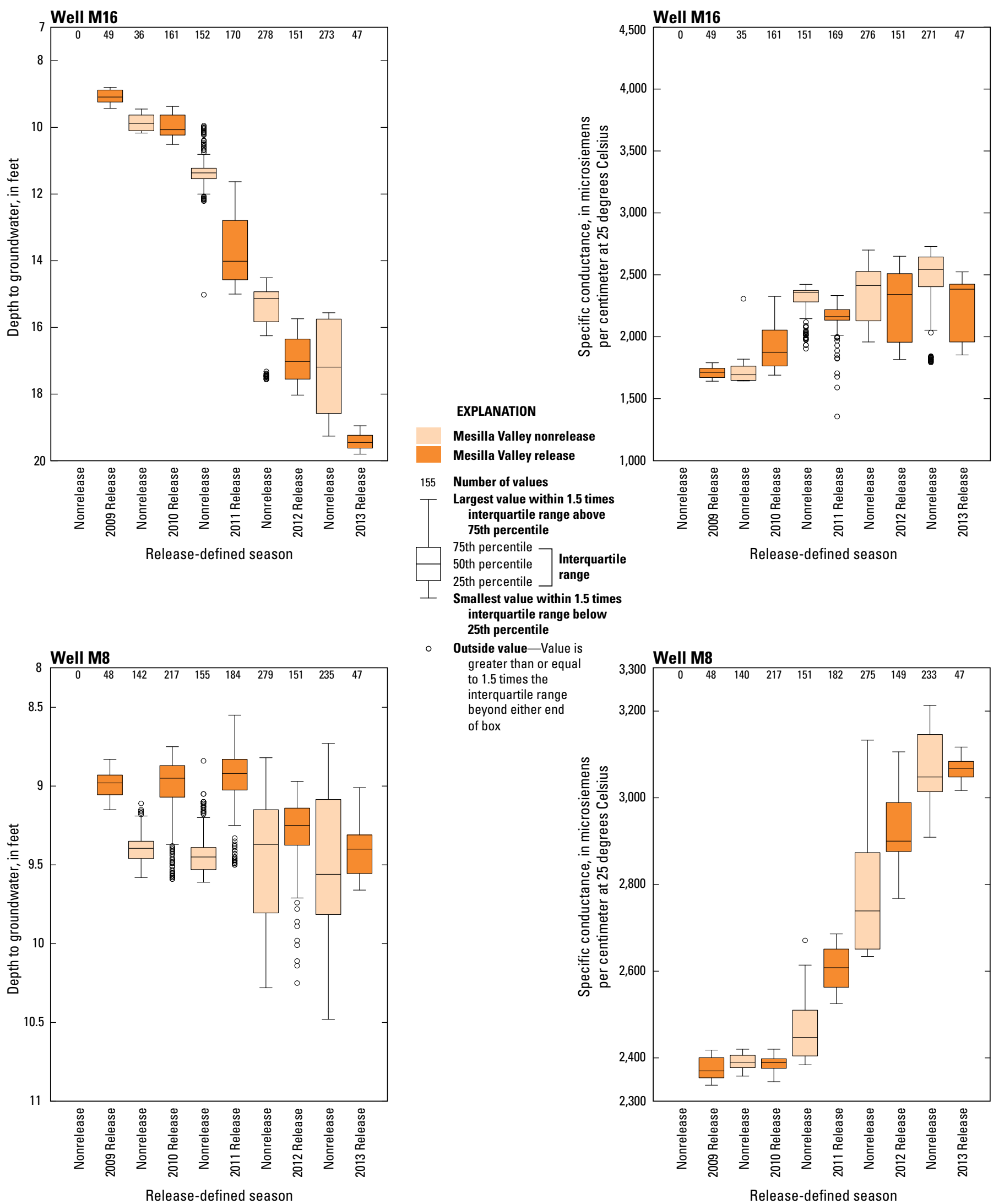

Figure 8. Seasonally grouped data showing overall and seasonal trends for depth to groundwater and specific conductance data for each shallow well in the Rio Grande Project area, New Mexico and Texas.-Continued 

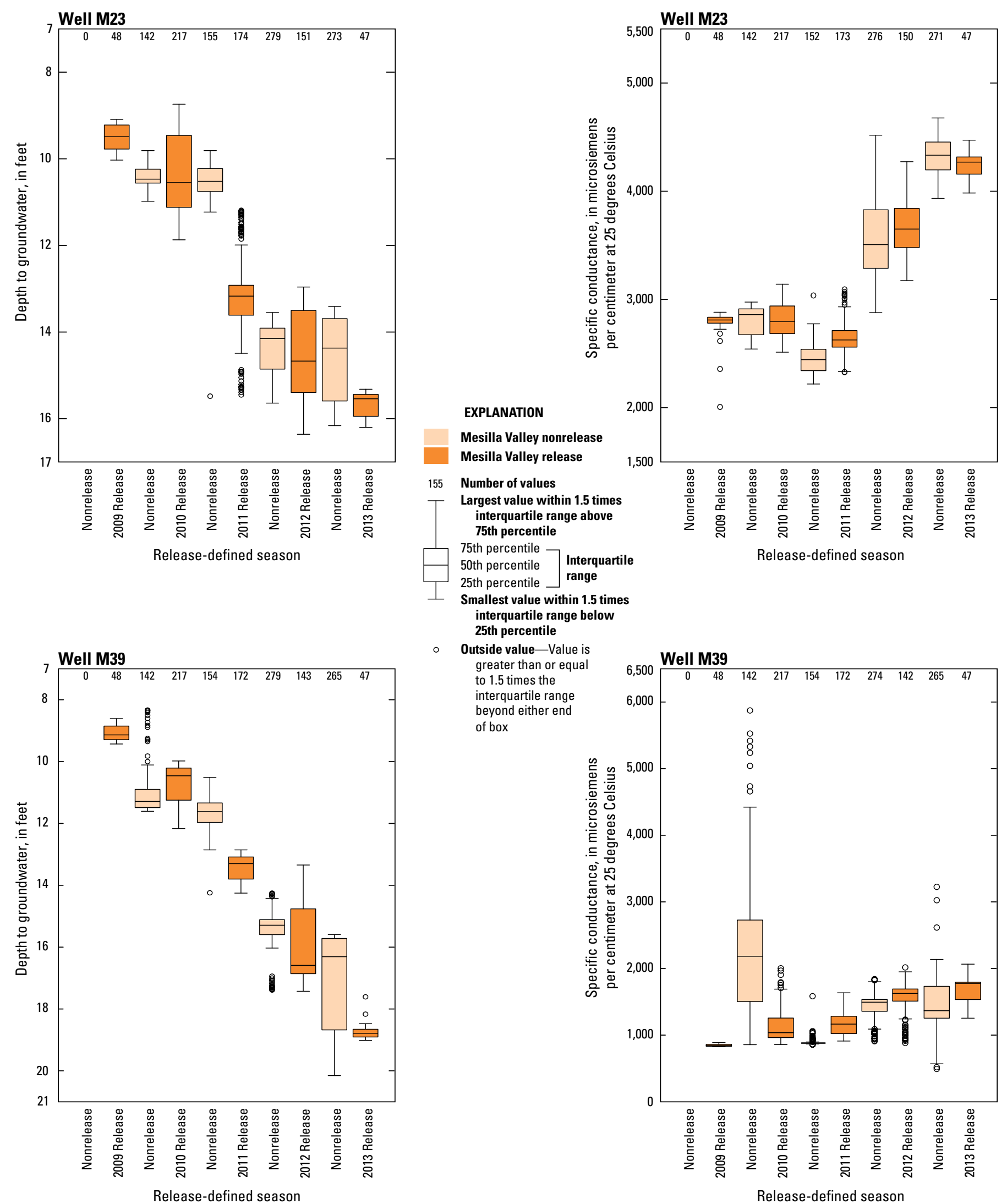

- Outside value-Value is greater than or equal to 1.5 times the interquartile range beyond either end of box

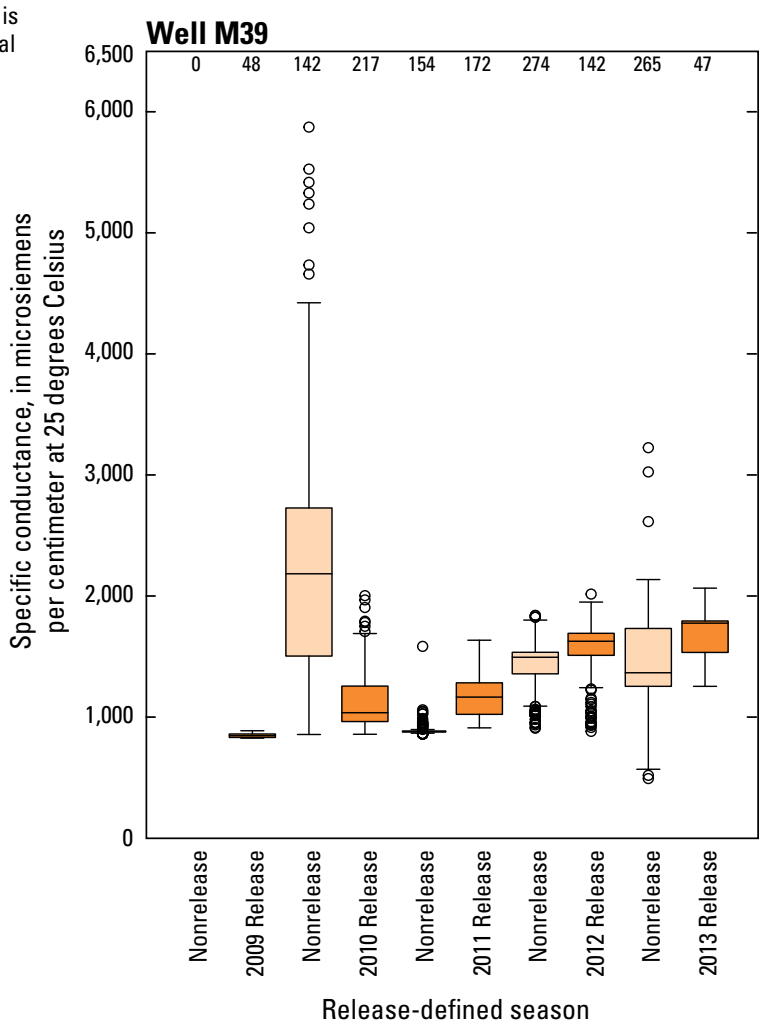

Figure 8. Seasonally grouped data showing overall and seasonal trends for depth to groundwater and specific conductance data for each shallow well in the Rio Grande Project area, New Mexico and Texas.-Continued 

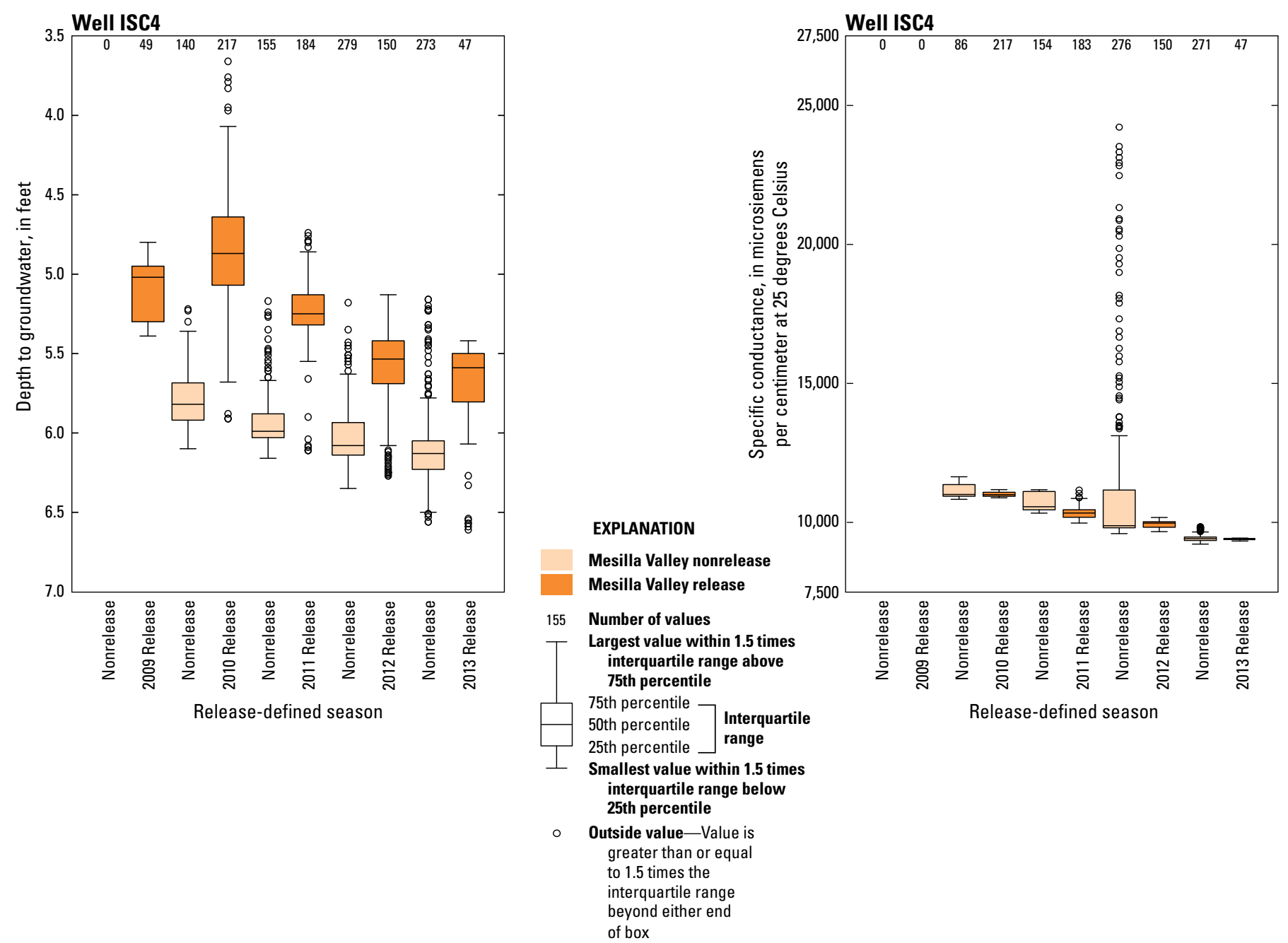

Figure 8. Seasonally grouped data showing overall and seasonal trends for depth to groundwater and specific conductance data for each shallow well in the Rio Grande Project area, New Mexico and Texas.-Continued 


\section{Variability of Surface-Water Quantity and Quality and Shallow Groundwater Levels and Quality}

\section{Seasonal Shallow Groundwater Trends}

Temporal trends within release-defined seasons in shallow groundwater were quantified by using the nonparameteric Mann-Kendall test (Helsel and Hirsch, 2002; McLeod, 2011). The resulting Mann-Kendall tau values are evaluated by finding the direction of change for each consecutive data point in the time series, which evaluates if there is an overall trend (increasing or decreasing) in the data. Mann-Kendall tau values were calculated for depth to groundwater and $\mathrm{SC}$ data over the entire study period, grouped into daily release and nonrelease seasons (table 5). The sign of the tau values indicates the direction of the trend (increasing trend has a positive tau value, decreasing trend has a negative tau value). Trends were considered statistically significant for $p$-values less than 0.05 . Consistent magnitude and directions of the trends in both seasons show a trend over the study period with no seasonal variability. Seasonally variable tau signs or magnitudes may indicate a temporal disconnection of dominant processes influencing the data.

Table 5. Seasonal Mann-Kendall tau values for all continuous groundwater data in the Rincon and Mesilla Valleys in the Rio Grande Project area, New Mexico and Texas, 2009-13.

[Release/nonrelease is the Caballo streamgage-defined season; MKT is the Mann-Kendall tau calculated by using daily values (ignoring missing data) within the given season for all years (all $p$-values $<0.05$, indicating trend is statistically significant); the sign of MKT water-level values was changed; negative value shows a decline of water level, and positive value shows a rise in water level]

\begin{tabular}{lccccc}
\hline \multirow{2}{*}{$\begin{array}{c}\text { Well } \\
\text { identifier }\end{array}$} & \multicolumn{4}{c}{ Mann-Kendall tau values } \\
\cline { 2 - 3 } & \multicolumn{2}{c}{ Groundwater level } & & \multicolumn{2}{c}{ Specific conductance } \\
\cline { 2 - 3 } \cline { 5 - 6 } Nonrelease & Release & & Nonrelease & Release \\
\hline H4 & -0.687 & -0.711 & & 0.607 & 0.301 \\
H13 & -0.551 & -0.112 & & -0.635 & -0.487 \\
H19 & -0.410 & -0.768 & & -0.309 & -0.634 \\
H30 & -0.533 & -0.588 & & -0.367 & 0.093 \\
H29 & -0.812 & -0.594 & & -0.354 & -0.295 \\
H27 & -0.671 & -0.548 & & 0.327 & 0.701 \\
H25 & -0.650 & -0.676 & & 0.511 & 0.457 \\
M43 & -0.636 & -0.450 & & -0.673 & -0.337 \\
M16 & -0.766 & -0.747 & & 0.366 & 0.357 \\
M8 & -0.144 & -0.211 & & 0.770 & 0.804 \\
M23 & -0.545 & -0.603 & & 0.570 & 0.339 \\
M39 & -0.854 & -0.650 & & 0.114 & 0.432 \\
ISC4 & -0.404 & -0.487 & -0.750 & -0.664 \\
\hline
\end{tabular}

Results show consistent negative tau values for daily data for depth to groundwater in both the Rincon and Mesilla Valleys (table 5). Depth to groundwater tau values for the wells range from -0.854 to -0.144 for nonrelease season and -0.768 to -0.112 for release season. Negative tau values at all wells indicate a consistent, overall decline in the shallow water table over the entire study period. Wells with the lowest magnitude tau values for depth to groundwater, and therefore possibly more influenced by surface water, are H13 (nonrelease season -0.551 , release season -0.112) and M8 (nonrelease season -0.144 , release season -0.211).

Tau values were also calculated using daily groundwater SC data for each well. Inconsistent tau values and signs (both positive and negative) at wells in the study area show temporal and spatial heterogeneity with respect to groundwater SC trends in both the Rincon and Mesilla Valleys (table 5). These results, compared to the lack of seasonal response of groundwater SC, show that the variability of groundwater quality is present at both interannual and intraannual timescales. Only 1 out of the 13 wells had a change in the direction of the trend with respect to season; the SC trend for H30 decreased during nonrelease seasons over the period of study, but the trend increased during release seasons over the period of study. Three (H13, H19, and H29) of the remaining six wells in the Rincon Valley show decreasing SC trends during both seasons, and three wells (H4, H25, and H27) show increasing SC trends during both seasons. Of the six wells in the Mesilla Valley, two (M43 and ISC4) show decreasing SC trends for both seasons and four (M8, M16, M23, and M39) show increasing SC trends for both seasons.

Daily groundwater-well data show no consistent valleywide response to surface-water conditions in either valley. This indicates a unique hydrologic setting for each well in the valley, with variable depth to groundwater and SC values relative to the proximity to the river, laterals and drains, crop activity, and irrigation practices. Each of these factors may have a different degree of influence on depth to groundwater and SC observed in individual wells. Wells located near conveyances (such as the river, laterals, or drains) could have groundwater levels and groundwater SC values influenced by the surface water in these conveyances. For example, during release season, increased head from surface water could result in lateral flow to the proximate shallow wells, increasing shallow groundwater levels. Lateral flow may also influence the shallow groundwater quality, resulting in $\mathrm{SC}$ values similar to those in surface water (an increase or decrease of shallow groundwater $\mathrm{SC}$ value varies relative to the nonrelease season shallow groundwater and the surface-water $\mathrm{SC}$ values). Wells located near different types of crops may show a different response because irrigation practices between farmers and crops vary; some crops require frequent flood irrigation, other crops may require less flood irrigation, and other crops might use a drip irrigation system. Multiple crop rotations may also be applied to the same land between years in the study. Wells located near irrigated crops may show a different response relative to the type and frequency of irrigation (for example, 
less water-level decline near frequently flood irrigated crops or more water-level decline near drip irrigated row crops). Flushing of accumulated salt from the unsaturated zone during irrigation may also result in an initial increase of SC during release season in shallow groundwater wells located near crops.

The source of irrigation water may cause fluctuations in the depth to groundwater and SC in opposite directions. Use of diverted surface water for flood irrigation could be expected to result in water-level rise and dilution of SC during the irrigation season because the SC of surface water is generally less than the SC of shallow groundwater within the study area (figs. 4 and 8). If groundwater is pumped and used for irrigation, and the monitoring well is located within the cone of depression of the irrigation well or within an area of widespread pumping for irrigation, water-level decline would be expected. Water applied to fields for irrigation increases SC as it travels through the unsaturated zone and dissolves salt until it reaches the water table. These increased-SC infiltrated irrigation waters may then return to the surface water system through the irrigation drains.

\section{Spatial Distribution of Groundwater-Level Trends Relative to Low-Flow Seepage Data}

Comparison of seepage-investigation results and depth to groundwater trends during the same nonrelease season may help identify the spatial distribution and temporal variability of surface-water/shallow groundwater exchange in the Mesilla Valley. A spatial correlation between gaining and losing surface-water reaches and shallow groundwater wells may indicate connectivity of the surface-water/groundwater systems through the nonrelease season. Spatial correlation of seepage data and depth to groundwater may identify areas of hydrologic connectivity or lack of hydrologic connectivity during the nonrelease season (when seepage data were collected). There may be spatially heterogeneous influences to shallow groundwater in the valley such as groundwater pumping and leakage from canals and drains during the irrigation season.

Statistically significant Mann-Kendall tau values for each well for the daily continuous data from each nonrelease season leading up to the release season were categorized as either positive or negative from the sign of the tau value (table 6). There are no depth to groundwater data for 2009 prior to the release season; therefore, depth to groundwater trends are not available to compare to seepage investigation results for the 2009 nonrelease season. Main-stem seepage data (Crilley
Table 6. Mann-Kendall tau values for daily depth to groundwater data from shallow wells in the Mesilla Valley for continuous nonrelease seasons (from the end of the previous year release season to the current year release season), 2009-13.

[NA, no data available; negative values indicate a decline in groundwater level; positive values indicate an increase in groundwater level; italics indicate results are statistically insignificant ( $\mathrm{p}$-value is $>0.05$ ) and all other values are statistically significant ( $\mathrm{p}$-value $<0.05)]$

\begin{tabular}{lccccc}
\hline \multirow{2}{*}{$\begin{array}{c}\text { Well } \\
\text { identifier }\end{array}$} & \multicolumn{5}{c}{ Mann-Kendall tau values } \\
\cline { 2 - 6 } & $\mathbf{2 0 0 9}$ & $\mathbf{2 0 1 0}$ & $\mathbf{2 0 1 1}$ & $\mathbf{2 0 1 2}$ & $\mathbf{2 0 1 3}$ \\
\hline M43 & NA & -0.847 & -0.846 & 0.012 & 0.060 \\
M16 & NA & -0.936 & -0.401 & -0.336 & -0.725 \\
M8 & NA & -0.863 & -0.693 & -0.32 & 0.502 \\
M23 & NA & -0.286 & -0.719 & 0.379 & -0.804 \\
M39 & NA & -0.940 & -0.978 & -0.391 & -0.921 \\
ISC4 & NA & 0.053 & -0.619 & -0.326 & 0.018 \\
\hline
\end{tabular}

and others, 2013) were categorized as gaining, losing, or neutral. Some reaches did not have any discharge; therefore, no data are shown for these sections. These categorical depth to groundwater and seepage data were evaluated for general spatial correlation for each nonrelease season (from 2009 to 2013) (fig. 9). Seepage investigation data show that although there were gaining reaches early in the study period along the Rio Grande during low flow, these reaches became neutral or losing by the end of the study period. Overall, depth to groundwater trends show mostly declining groundwater levels, and seepage data show mostly losing reaches. Positive depth to groundwater trends were found in wells M23 in 2012 and M8 in 2013. Well M23 is located just downgradient from what was measured to be a neutral seepage reach in 2012, whereas the increasing trend at well M8 in 2013 occurred at a time when the nearest river reach had no flow. An increasing depth to water trend may indicate a disconnection between river and groundwater and (or) an influence from canal or drain leakage on depth to groundwater at this location at the aforementioned times. The overall negative trend in depth to groundwater over the study period and the lack of available groundwater data to compare to the 2009 and 2010 seepage data, when there were gaining seepage reaches, yielded inconclusive results for this spatiotemporal analysis on surface-water/groundwater exchange. 


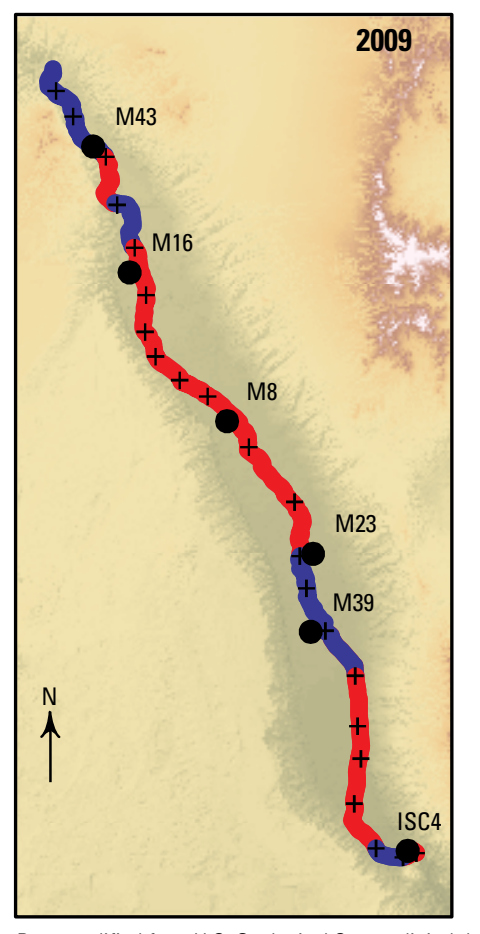

Base modified from U.S. Geological Survey digital data Universal Transverse Mercator, zone 13

North American Datum of 1983

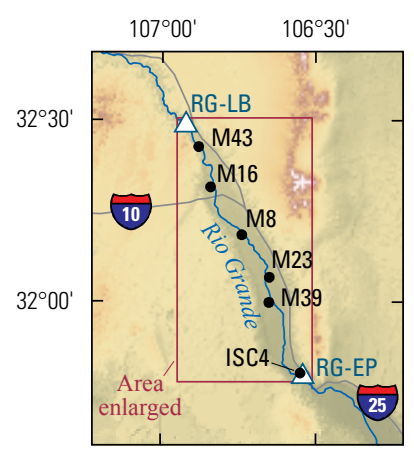

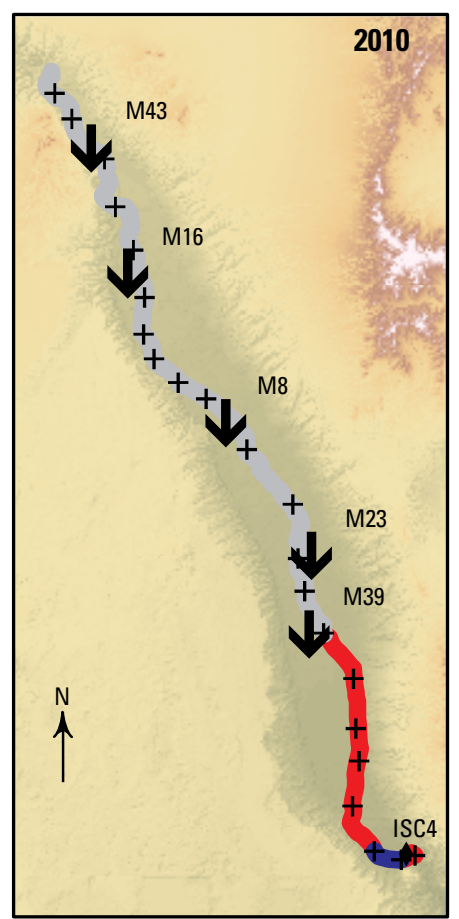
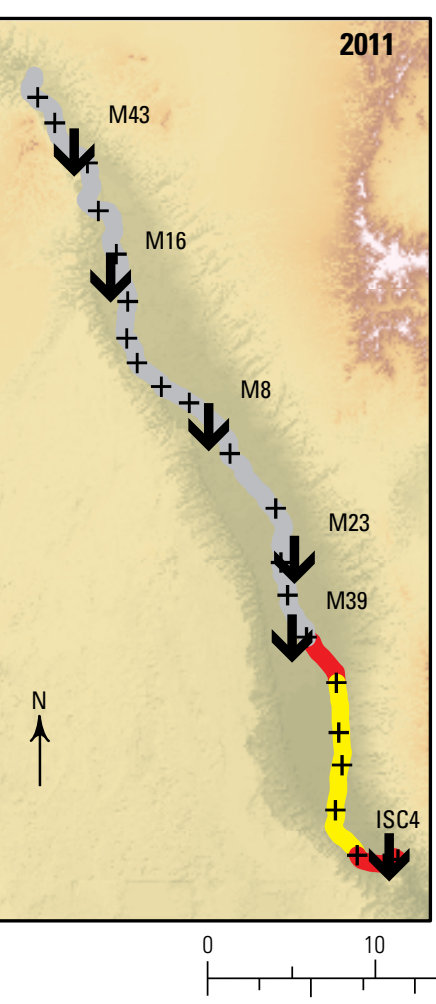

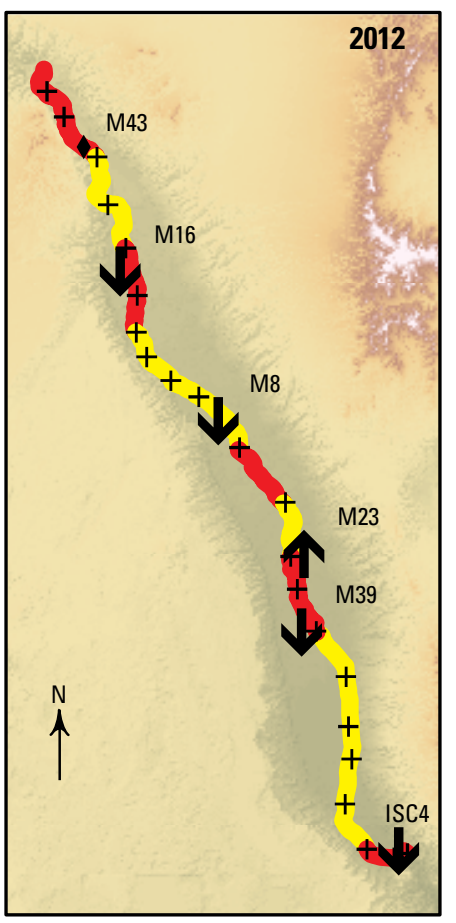

20 MILES

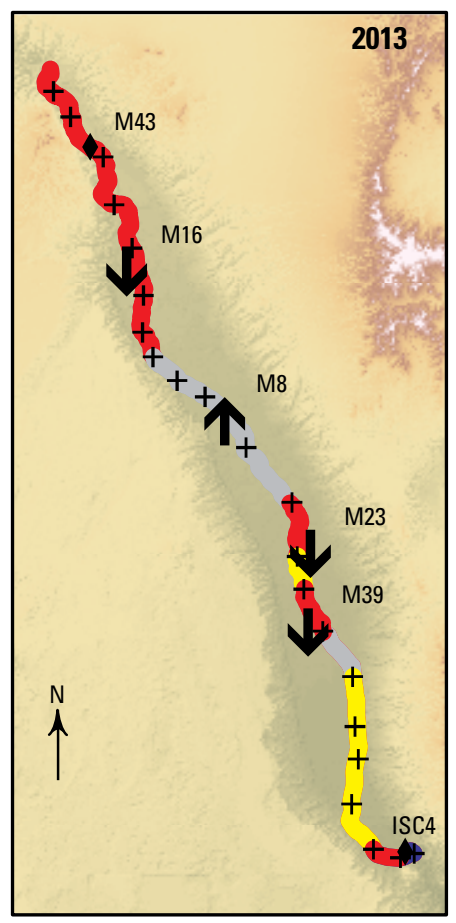

EXPLANATION

Low-flow seepage

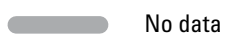

Losing reach

No loss or gain

Gaining reach

Nonrelease water-level trend

VDecreasing water level

- No statistically significant trend

A Increasing water level

M39 Monitoring well identifier

$+\quad$ Seepage site

Figure 9. Spatial distribution of low-flow seepage results (from Crilley and others, 2013) and nonrelease groundwater-level trends in the Mesilla Valley, Rio Grande Project area, New Mexico and Texas, 2009-13. 


\section{Annual Dissolved-Solids Loads and Climatic and Anthropogenic Variables}

Annual data for potential anthropogenic and climatic drivers of surface-water and groundwater conditions were collected to evaluate the linear correlation between drivers and hydrologic response over the study period. The power of these correlations is somewhat limited by the number of years of available data; continued data collection would increase the significance of this statistical analysis. The values of these driver variables represent climatic forcing or anthropogenic (human-influenced) forcing with a component of climatic forcing, such as for Rio Grande Project operations (gross diversion, cumulative Caballo Reservoir release volume) and agricultural practices (total irrigated acreage, volume of pumped groundwater for irrigation). Anthropogenic and climatic drivers included in this analysis were gross annual (actual) diversion for the Rio Grande Project area (Bureau of Reclamation, 2013b), total irrigated acreage for the Rio Grande Project area (Bureau of Reclamation, 2013b), cumulative volume released from Caballo Dam at RG-CB during release season, volume of pumped groundwater for irrigation for the Rio Grande Project area (R.J. Serrano, unpub. data, 2014), and the annual mean of monthly Palmer Drought Severity Index (PDSI) values calculated for the Rio Grande-Caballo hydrologic unit region of southern New Mexico (University of Idaho and Desert Research Institute, 2015). Of note, some anthropogenic drivers are initially forced by climatic conditions; for example, the volume of water released at Caballo Dam is the result of management decisions that are influenced by climate and upstream storage, as well as by legal obligations of downstream water users. Response variables included in the analysis for both the Rincon and Mesilla Valleys were cumulative annual DS load, annual mean depth to groundwater, and annual mean SC (table 7). The PDSI was chosen as the climatic driver variable because it is a comprehensive measure of climate that is based on soil moisture (which integrates both temperature and precipitation factors) (Palmer, 1965). The PDSI values are evaluated monthly and can be positive or negative; values near zero (-0.49 to 0.49$)$ indicate a near-normal climate, and the magnitude of the value away from zero indicates the severity of the deviation from normal climate. The PDSI values less than -3.0 indicate a severe drought.

Pearson's $r$ (a measure of linear correlation between two variables; Helsel and Hirsch, 2002) was calculated and compared to $p$-values (a reporting convention that is used to report on the chance of or the hypothesis from statistical tests; $p$-values greater than 0.05 indicate that the data are statistically similar, and $p$-values less than 0.05 indicate that the data are statistically different) for each combination of variable pairs for annual data from 2009 to 2013 (table 8). Statistical significance was defined as $p$-values less than 0.05 ; however, linear correlation of annual data over the study period is somewhat limited because of the number of data points.
An increased temporal range would improve the statistical rigorousness of this analysis.

Annual DS loads in the Rincon Valley show a significant positive correlation with the gross diversion, whereas annual DS loads in the Mesilla Valley show a nonsignificant negative correlation to the gross diversion. The correlation between salt loading and irrigation-related variables may indicate a processes-based relation between salt loading and agriculture in the Rincon and Mesilla Valleys. The difference in these correlations in the Rincon and Mesilla Valleys highlights the negative trend of cumulative salt loading in the Mesilla Valley compared to the positive trend of cumulative salt loading in the Rincon Valley. There are no statistically significant correlations for groundwater quality (DS or SC) for any driver variables included in this analysis in either valley, which suggests temporal heterogeneity of groundwater quality in the study area.

\section{Comparison of Current and Previous Drought Effects in the Rio Grande Project Area}

Drought conditions in the 1950s in New Mexico are reported to have influenced surface-water quality and depth to groundwater in the study area (Thomas and others, 1963; Wilson and others, 1981; Williams, 2001; Moyer and others, 2013). Depths to groundwater in the Mesilla Valley during this period were initially annually constant but increased seasonally during irrigation seasons from 1946 to 1952. A breakdown of seasonal variability showed a decline in groundwater levels from 1952 to 1956, followed by an increase in groundwater levels after 1956 (Thomas and others, 1963). These basin-averaged groundwater data do not show the spatial complexity and heterogeneity highlighted by the well-by-well data from this study.

Time series of mass-balance DS loads between streamgages (upstream minus downstream) on the Rio Grande show an increase in change in salt load within the Mesilla Valley (source of salt) and a slight decrease in change in salt loads in the Rincon Valley (sink of salt) during the 1950s (Williams, 2001; Moyer and others, 2013). The same general trends were observed from annual basin-scale DS loads (change in loads between streamgages) from 2009 to 2013 (fig. 6). Drawing the conclusion that these trends are driven by drought is tempting; however, a similar trend also was observed in the 1980s, which was a very wet climatic period (Moyer and others, 2013). A change in the composition of salts contributing to DS may explain these similar loading patterns during very different climatic conditions. The 1950s DS loads were strongly influenced by sodium and chloride, which are geologically derived salts, whereas the 1980s DS loads were influenced more by sulfate (Williams, 2001), which has both geologic and anthropogenic sources (Szynkiewicz and others, 2011). Sulfur isotopes (along with other hydrochemical data) were used in a principal component analysis by Szynkiewicz and others (2011) to find the relative contribution of 


\section{Variability of Surface-Water Quantity and Quality and Shallow Groundwater Levels and Quality}

Table 7. Annual driver and response variables from various sources for the Rincon and Mesilla Valleys, in the Rio Grande Project area, New Mexico and Texas, 2009-13.

[NA, not available]

\begin{tabular}{|c|c|c|c|c|c|c|}
\hline Variable & Units & 2009 & 2010 & 2011 & 2012 & 2013 \\
\hline $\begin{array}{l}\text { Cumulative Caballo release } \\
\text { volume }\end{array}$ & cubic meters & $854,768,160$ & $812,643,840$ & $488,634,336$ & $454,881,312$ & $207,298,656$ \\
\hline $\begin{array}{l}\text { Volume of pumped } \\
\text { groundwater for } \\
\text { irrigation }^{3}\end{array}$ & acre-feet & 130,540 & 137,630 & 279,368 & 265,321 & 286,050 \\
\hline $\begin{array}{l}\text { Palmer Drought Severity } \\
\text { Index (annual mean) }\end{array}$ & (no units) & -1.86 & 1.93 & -3.39 & -2.18 & -2.54 \\
\hline $\begin{array}{l}\text { Rincon Valley depth to } \\
\text { groundwater (annual } \\
\text { mean) }\end{array}$ & feet & 10.40 & 11.56 & 13.04 & 14.47 & 15.53 \\
\hline $\begin{array}{l}\text { Rincon groundwater } \\
\text { specific conductance } \\
\text { (annual mean) }\end{array}$ & $\begin{array}{l}\text { microsiemens } \\
\text { per centimeter } \\
\text { at } 25 \text { degrees } \\
\text { Celsius }\end{array}$ & $2,481.8$ & $2,414.9$ & $2,414.4$ & $2,472.8$ & $2,381.5$ \\
\hline $\begin{array}{l}\text { Mesilla Valley cumulative } \\
\text { annual dissolved-solids } \\
\text { load }\end{array}$ & tons & 6,149 & 30,697 & 43,344 & 122,171 & 78,898 \\
\hline
\end{tabular}

${ }^{1}$ Elephant Butte Irrigation District Annual Project Allocations, charges and releases under the Operating Agreement (actual) from table 3.3-1 (https://www. usbr.gov/uc/albuq/envdocs/ea/riogrande/op-Proced/Supplemental/Appdx.pdf).

${ }^{2}$ Elephant Butte Irrigation District Annual Project Allocations, charges and releases under the Operating Agreement (actual) from table 3.1-3 (https://www. usbr.gov/uc/albuq/envdocs/ea/riogrande/op-Proced/Supplemental/Appdx.pdf).

${ }^{3}$ R.J. Serrano, unpub. data, 2014.

${ }^{4}$ University of Idaho and Desert Research Institute, 2015, WestWide Drought Tracker (http://www.wrcc.dri.edu/wwdt/). 
Table 8. Pearson's $r$ values between driver and response variables (table 6) in the Rincon and Mesilla Valleys, in the Rio Grande Project area, New Mexico and Texas, 2009-13.

[Linear correlation coefficient Pearson's $r$ with $p$-value in parentheses, values in bold indicate statistical significance $(p<0.05)$. n, number of values in statistical analysis]

\begin{tabular}{|c|c|c|c|c|c|}
\hline \multirow[b]{2}{*}{ Response variables } & \multicolumn{5}{|c|}{ Driver variables } \\
\hline & $\begin{array}{l}\text { Gross diversion } \\
\text { (actual) } \\
(\mathrm{n}=4)\end{array}$ & $\begin{array}{c}\text { Total } \\
\text { irrigated acreage } \\
\text { (Rincon Valley and } \\
\text { Mesilla Valley) } \\
(n=4)\end{array}$ & $\begin{array}{l}\text { Cumulative } \\
\text { Caballo } \\
\text { release volume } \\
(n=5)\end{array}$ & $\begin{array}{c}\text { Volume of pumped } \\
\text { groundwater } \\
\text { for irrigation } \\
(n=5)\end{array}$ & $\begin{array}{c}\text { Palmer Drought } \\
\text { Severity Index } \\
\text { (annual mean) } \\
\quad(n=5)\end{array}$ \\
\hline $\begin{array}{l}\text { Rincon annual dissolved-solids } \\
\text { load }\end{array}$ & $0.9740(p=0.026)$ & $0.9319(p=0.068)$ & $0.6640(p=0.222)$ & $-0.8213(p=0.088)$ & $0.5802(p=0.305)$ \\
\hline $\begin{array}{l}\text { Rincon depth to groundwater } \\
\text { (annual mean) }\end{array}$ & $-0.9650(p=0.035)$ & $-0.9395(p=0.060)$ & $-0.9687(p=0.006)$ & $0.8955(p=0.040)$ & $-0.4481(p=0.449)$ \\
\hline $\begin{array}{l}\text { Rincon groundwater specific } \\
\text { conductance (annual mean) }\end{array}$ & $0.0806(p=0.919)$ & $0.2134(p=0.787)$ & $0.5453(p=0.342)$ & $-0.4155(p=0.487)$ & $-0.0511(p=0.935)$ \\
\hline $\begin{array}{l}\text { Mesilla annual dissolved-solids } \\
\text { load }\end{array}$ & $-0.8336(p=0.166)$ & $-0.6845(p=0.315)$ & $-0.7213(p=0.169)$ & $0.7241(p=0.166)$ & $-0.3036(p=0.619)$ \\
\hline $\begin{array}{l}\text { Mesilla groundwater specific } \\
\text { conductance (annual mean) }\end{array}$ & $-0.6756(p=0.3244)$ & $-0.7121(p=0.2879)$ & $-0.5821(p=0.303)$ & $0.6092(p=0.275)$ & $0.1056(p=0.866)$ \\
\hline
\end{tabular}

anthropogenic and natural sulfate sources to Mesilla Valley groundwater in 2008. The analysis found similar contributions from natural and anthropogenic sources: 38 percent of total variance was likely from geologic sources, and 35 percent of total variance was likely from anthropogenic sources (the source of the remaining 27 percent of total variance could not be determined using the methodology of the study). Additional longer-term and (or) higher frequency water-quality sampling could measure the consistency of contribution of these natural and anthropogenic and salt sources to surface-water quality relative to reservoir release operations.

\section{Summary and Conclusions}

Reduced surface-water availability caused by recent drought has reduced the volume of release from the storage infrastructure of the Rio Grande Project, leading to changes in conjunctive water use in downgradient alluvial valleys from January 1, 2009, to September 30, 2013. In 2013, the U.S. Geological Survey, in cooperation with the New Mexico Environment Department and the New Mexico Interstate Stream Commission, began a study to (1) calculate dissolved-solids loads over the study period at streamgages in the study area where data are available, (2) assess the temporal variability of dissolved-solids loads at and between each streamgage where data are available, and (3) relate the spatiotemporal variability of shallow groundwater data (depth to groundwater and quality) within the alluvial valleys of the study area to the spatiotemporal variability of surface-water data over the study period. Intraannual seasons were defined by the release volume from Caballo Reservoir as release and nonrelease seasons that are temporally dynamic. Analysis of cumulative annual dissolved-solids loading from 2009 to 2013 shows the majority of salt loading occurs during the release season at each streamgage. Salt-load mass balance between streamgages over the study period shows contrasting trends in the Rincon and Mesilla Valleys. In the Rincon Valley, there is a decreasing sink of salt on an annual scale, but the valley is a source of salt during the nonrelease season over the study period. In the Mesilla Valley, there is an increasing sink of salt on an annual scale, as more salt enters than leaves the valley annually over the study period. Recycling of water, and thus salt (through conjunctive use), may keep salt in the basin playing a role in surface-water quality in the Mesilla Valley. Spatial heterogeneity of individual shallow groundwater-well data shows the local influence from sources such as irrigation practices and/or canal leakage. Similar temporal trends in mass-balance salt loading between this study and a study of the drought during the 1950s may indicate similar hydrologic processes controlling salt loading during times of drought. However, trends during a wet period in the 1980s also were similar to those observed during this study. The similarity of these trends independent of the climate indicates salt loading in this hydrologic setting may be driven by water-use practices rather than a single climatic variable. 


\section{References Cited}

Anderholm, S.K., 2002, Water-quality assessment of the Rio Grande Valley, Colorado, New Mexico, and TexasSurface-water quality, shallow ground-water quality, and factors affecting water quality in the Rincon Valley, Southcentral New Mexico, 1994-95: U.S. Geological Survey Water-Resources Investigations Report 2002-4188, 117 p.

Anning, D.W., Bauch, N.J., Gerner, S.J., Flynn, M.E., Hamlin, S.N., Moore, S.J., Schaefer, D.H., Anderholm, S.K., and Spangler, L.E., 2007, Dissolved solids in basin-fill aquifers and streams in the southwestern United States: U.S. Geological Survey Scientific Investigations Report 2006$5315,168 \mathrm{p}$.

Autobee, Robert, 1994, Rio Grande Project-Project history: Bureau of Reclamation, p. 33, accessed June 25, 2015, at http://www.usbr.gov/projects/Project.jsp?proj_ Name $=$ Rio $\% 20$ Grande $\% 20$ Project.

Bothern, L.R., 2003, Geothermal salt intrusion into Mesilla Basin aquifers and the Rio Grande, Dona Ana County, New Mexico, USA: Las Cruces, N. Mex., New Mexico State University, Master's thesis, 126 p., accessed November 25, 2014, at http://www.wrri.nmsu.edu/publish/techrpt/tr330/ $\mathrm{CD} /$ appendix-b/Bothern-thesis/bothern-thesis.pdf.

Bureau of Reclamation, 2008, Operating agreement for the Rio Grande Project: Bureau of Reclamation, p. 23.

Bureau of Reclamation, 2009, Elephant Butte Reservoir FiveYear Operational Plan: Bureau of Reclamation Biological Assessment, p. 90.

Bureau of Reclamation, 2013a, Rio Grande Project-Analysis of surface water and groundwater resources under the 2008 operating agreement: Bureau of Reclamation Technical Memorandum no. 86-68210-2013-3.

Bureau of Reclamation, 2013b, Supplemental environmental assessment-Implementation of the Rio Grande Project Operating Procedures, New Mexico and Texas: Bureau of Reclamation, 89 p. plus appendixes, accessed November 26, 2014, at http://www.usbr.gov/uc/albuq/envdocs/ea/ riogrande/op-Proced/Supplemental.

Conover, C.S., 1954, Ground-water conditions in the Rincon and Mesilla Valleys and adjacent areas in New Mexico: U.S. Geological Survey Water Supply Paper 1230.

Crilley, D.M., Matherne, A.M., Thomas, N.I., and Falk, S.E., 2013, Seepage investigations of the Rio Grande from below Leasburg Dam, Leasburg, New Mexico, to above American Dam, El Paso, Texas, 2006-13: U.S. Geological Survey Open-File Report 2013-1233, 34 p., accessed July 22, 2014, at http://pubs.usgs.gov/of/2013/1233.
Eastoe, C.J., Hibbs, B.J., Olivas, A.G., Hogan, J.F., Hawley, J., and Hutchison, W.R., 2008, Isotopes in the Hueco Bolson aquifer, Texas (USA) and Chihuahua (Mexico) - Local and general implications for recharge sources in alluvial basins: Hydrogeology Journal, v. 16, no. 4, p. 737-747.

Ennis, D.J., 2009, Lower Rio Grande monitoring well installation summary report: Souder, Miller \& Associates, $335 \mathrm{p}$.

Gunn, M.A., and Roark, D.M., 2014, Seepage investigation on the Rio Grande from below Caballo Reservoir to El Paso, Texas, 2012: U.S. Geological Survey Scientific Investigations Report 2014-5197, 17 p., http://dx.doi. org/10.3133/sir20145197.

Hawley, J.W., and Kennedy, J.F., 2004, Creation of a digital hydrogeologic framework model of the Mesilla Basin and Southern Jornada del Muerto Basin: New Mexico Water Resources Research Institute Technical Completion Report 332, p. 105.

Hawley, J.W., Kennedy, J.F., Granados-Olivias, A., and Ortiz, M.A., 2009, Hydrogeologic framework of the binational Western Hueco Bolson-Paso del Norte area, Texas, New Mexico and Chihuahua - Overview and progress report on digital-model development: New Mexico Water Resources Research Institute WRRI Technical Completion Report no. 349 , p. 45.

Helsel, D.R., and Hirsch, R.M., 2002, Statistical methods in water resources: U.S. Geological Survey Techniques of Water Resources Investigations, book 4, chap. A3, 522 p.

Hibbs, B.J., and Merino, M., 2007, Discovering a geologic salinity source in the Rio Grande aquifer: Southwest Hydrology, v. 6, no. 4, p. 3.

Hogan, J.F., Phillips, F.M., Mills, S.K., Hendrickx, J.M.H., Ruiz, J., Chesley, J.T., and Asmerom, Y., 2007, Geologic origins of salinization in a semi-arid river-The role of sedimentary basin brines: Geology, v. 35, no. 12, p. 1063.

McKean, S.E., Matherne, A.M., and Thomas, N., 2014, Water quality, discharge, and groundwater levels in the Palomas, Mesilla, and Hueco Basins in New Mexico and Texas from below Caballo Reservoir, New Mexico, to Fort Quitman, Texas, 1889-2013: U.S. Geological Survey Data Series 884, accessed November 24, 2014, at http://dx.doi.org/10.3133/ ds 884 .

McLeod, A.I., 2011, Kendall—Kendall rank correlation and Mann-Kendall trend test: R-Package, version 2.2, accessed February 24, 2015, at http://cran.r-project.org/web/ packages/Kendall/index.html.

Middle Rio Grande Conservancy District, 2012, MRGCD Conveyances/Facilities, accessed March 10, 2014, at http:// mrged.com/Mapping-GIS_Overview.aspx. 
Moore, S.J., Bassett, R.L., Liu, B., Wolf, C.P., and Doremus, D., 2008, Geochemical tracers to evaluate hydrogeologic controls on river salinization: Ground Water, v. 46, no. 3, p. 489-501.

Moyer, D.L., Anderholm, S.K., Hogan, J.F., Phillips, F.M., Hibbs, B.J., Witcher, J.C., Matherne, A.M., and Falk, S.E., 2013, Knowledge and understanding of dissolved solids in the Rio Grande-San Acacia, New Mexico, to Fort Quitman, Texas, and plan for future studies and monitoring: U.S. Geological Survey Open-File Report 2013-1190, p. 67.

Palmer, W.C., 1965, Meteorological drought: U.S. Department of Commerce Research Paper no. 45, p. 65.

Phillips, F.M., Mills, S., Hendrickx, M.H., and Hogan, J., 2003, Environmental tracers applied to quantifying causes of salinity in arid-region rivers-Results from the Rio Grande Basin, Southwestern USA, in Alsharhan, A.S., and Wood, W.W., eds., Developments in water science, water resources perspectives - Evaluation, Management and Policy: Elsevier, v. 50, p. 327-334.

Serrano, R.J., 2014, Lower Rio Grande Water Master Annual Report 2013 Accounting Period to the Office of the State Engineer: New Mexico Office of the State Engineer, unpublished report.

Szynkiewicz, Anna, Witcher, J.C., Modelska, M., Borrok, D.M., and Pratt, L.M., 2011, Anthropogenic sulfate loads in the Rio Grande, New Mexico (USA): Chemical Geology, v. 283, no. 3-4, p. 194-209.

Thomas, H.E., and others, 1963, Effects of drought in the Rio Grande Basin-Drought in the southwest 1942-56: U.S. Geological Survey Geological Survey Professional Paper 372-D, p. 63.
U.S. Census Bureau, 2010, 2010 TIGER/Line Shapefiles: U.S. Census Bureau, accessed March 10, 2014, at http://www. census.gov/geo/maps-data/data/tiger-line.html.

U.S. Geological Survey, 2015, National Water Information System-Web interface: Accessed February 18, 2015, at http://waterdata.usgs.gov/nwis.

University of Idaho and Desert Research Institute, 2015, WestWide Drought Tracker: Accessed February 25, 2015, at http://www.wrcc.dri.edu/wwdt.

Wagner, R.J., Boulger, R.W., Jr., Oblinger, C.J., and Smith, B.A., 2006, Guidelines and standard procedures for continuous water-quality monitors-Station operation, record computation, and data reporting: U.S. Geological Survey Techniques and Methods, book 1, chap. D3, 51 p.

Williams, J.H., 2001, Salt balance in the Rio Grande Project from San Marcial, New Mexico to Fort Quitman, TexasTransitions in Water and Environmental Resources Management: Las Cruces, New Mexico State University, Master's thesis, $110 \mathrm{p}$.

Wilson, C.A., White, R.R., Orr, B.R., and Roybal, R.G., 1981, Water resources of the Rincon and Mesilla Valleys and adjacent areas, New Mexico: New Mexico Office of the State Engineer Technical Report 43, 514 p.

Witcher, J.C., King, J.P., Hawley, J.W., Kennedy, J.F., Williams, J., Cleary, M., and Bothern, L.R., 2004, Sources of salinity in the Rio Grande and Mesilla Basin groundwater: New Mexico Water Resources Research Institute WRRI Technical Completion Report no. 330, $168 \mathrm{p}$. 


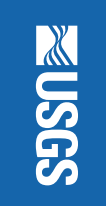

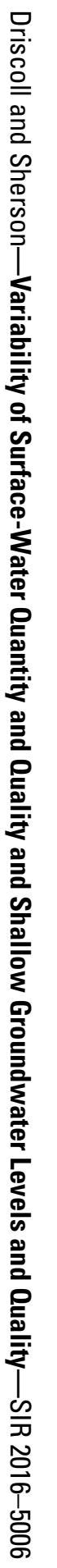

